\title{
Impact of Altered Cholinergic Tones on the Neurovascular Coupling Response to Whisker Stimulation
}

\author{
Clotilde Lecrux, ${ }^{1,2}$ Claire H. Sandoe, ${ }^{1}$ Sujaya Neupane, ${ }^{2}$ Pascal Kropf, ${ }^{2}$ ○avier Toussay, ${ }^{1}$ Xin-Kang Tong, ${ }^{1}$ \\ María Lacalle-Aurioles, ${ }^{1}$ Amir Shmuel, ${ }^{2}$ and ${ }^{\circ}$ Edith Hamel $^{1}$ \\ ${ }^{1}$ Laboratory of Cerebrovascular Research and ${ }^{2}$ Laboratory of Brain Imaging Signals, Montreal Neurological Institute, McGill University, Montréal, Quebec, \\ Canada H3A 2B4
}

Brain imaging techniques that use vascular signals to map changes in neuronal activity rely on the coupling between electrophysiology and hemodynamics, a phenomenon referred to as "neurovascular coupling" (NVC). It is unknown whether this relationship remains reliable under altered brain states associated with acetylcholine $(\mathrm{ACh})$ levels, such as attention and arousal and in pathological conditions such as Alzheimer's disease. We therefore assessed the effects of varying ACh tone on whisker-evoked NVC responses in rat barrel cortex, measured by cerebral blood flow (CBF) and neurophysiological recordings (local field potentials, LFPs). We found that acutely enhanced ACh tone significantly potentiated whisker-evoked CBF responses through muscarinic ACh receptors and concurrently facilitated neuronal responses, as illustrated by increases in the amplitude and power in high frequencies of the evoked LFPs. However, the cellular identity of the activated neuronal network within the responsive barrel was unchanged, as characterized by c-Fos upregulation in pyramidal cells and GABA interneurons coexpressing vasoactive intestinal polypeptide. In contrast, chronic ACh deprivation hindered whisker-evoked CBF responses and the amplitude and power in most frequency bands of the evoked LFPs and reduced the rostrocaudal extent and area of the activated barrel without altering its identity. Correlations between LFP power and CBF, used to estimate NVC, were enhanced under high ACh tone and disturbed significantly by ACh depletion. We conclude that ACh is not only a facilitator but also a prerequisite for the full expression of sensory-evoked NVC responses, indicating that ACh may alter the fidelity of hemodynamic signals in assessing changes in evoked neuronal activity.

Key words: acetylcholine; hemodynamics; interneurons; neurovascular coupling; pyramidal cells

Significance Statement

Neurovascular coupling, defined as the tight relationship between activated neurons and hemodynamic responses, is a fundamental brain function that underlies hemodynamic-based functional brain imaging techniques. However, the impact of altered brain states on this relationship is largely unknown. We therefore investigated how acetylcholine (ACh), known to drive brain states of attention and arousal and to be deficient in pathologies such as Alzheimer's disease, would alter neurovascular coupling responses to sensory stimulation. Whereas acutely increased ACh enhanced neuronal responses and the resulting hemodynamic signals, chronic loss of cholinergic input resulted in dramatic impairments in both types of sensory-evoked signals. We conclude that $\mathrm{ACh}$ is not only a potent modulator but also a requirement for the full expression of sensory-evoked neurovascular coupling responses.

\section{Introduction}

Neurovascular coupling (NVC) is a fundamental brain function defined as the tight coupling between neurophysiological and

Received May 25, 2016; revised Dec. 22, 2016; accepted Dec. 30, 2016

Author contributions: C.L., C.H.S., A.S., and E.H. designed research; C.L., C.H.S., P.K., X. Toussay, and X. Tong performed research; S.N. and M.L.-A. contributed unpublished reagents/analytic tools; C.L., C.H.S., S.N., P.K., X. Toussay, X. Tong, and M.L.-A. analyzed data; C.L., C.H.S., S.N., M.L.-A., A.S., and E.H. wrote the paper.

This work was supported by the Canadian Institute of Health Research (Grants MOP-84209 and MOP-142417 to E.H. and Grant MOP-102599 to A.S.), the Heart and Stroke Foundation of Canada (E.H.), the Human Frontier Science Program (Grant RGY0080/2008 to A.S.), a Jeanne Timmins Costello Postdoctoral Fellowship (C.L.), and a Jeanne hemodynamic signals. Accordingly, NVC underlies brain imaging techniques such as fMRI, SPECT, and PET, which assess neuronal activity indirectly through vascular signals. NVC has been characterized extensively under physiological conditions (Logo-
Timmins Costello Studentship (C.H.S.). We thank Dr. Zeshan Yao (Montreal Neurological Institute) for help with data acquisition and to Dr. Shmuel Na'aman (Montreal Neurological Institute) for help with data registration. The authors declare no competing financial interests.

Correspondence should be addressed to Dr. Clotilde Lecrux, Laboratory of Cerebrovascular Research, Montreal Neurological Institute, 3801 University Street, Montréal, Quebec, Canada H3A 2B4. E-mail: clotilde.lecrux@mcgill.ca. DOI:10.1523/JNEUROSCI.1784-16.2016

Copyright $\odot 2017$ the authors $\quad 0270-6474 / 17 / 371518-14 \$ 15.00 / 0$ 
thetis et al., 2001; Lauritzen and Gold, 2003; Niessing et al., 2005; Shmuel et al., 2006). However, brain imaging techniques are used over a wide range of brain states, so it is of the utmost importance to ascertain whether NVC is maintained when brain states are altered in both normal physiological conditions and in neurological diseases.

NVC and its mediators have been largely investigated in the glutamate-mediated whisker-to-barrel pathway. The barrel cortex contains a topographical representation of each whisker (Lübke and Feldmeyer, 2007), allowing a precise assessment of the relationship between evoked neuronal activity and changes in cerebral blood flow (CBF) (Staiger et al., 2000; Lecrux et al., 2011). In the barrel cortex, whisker stimulation activates pyramidal cells and specific GABA interneurons that colocalize vasoactive intestinal polypeptide (VIP), whereas those containing somatostatin (SOM) are largely inhibited (Gentet et al., 2012, Lecrux et al., 2011), as was also reported recently in other sensory modalities (Pi et al., 2013; Fu et al., 2014; Mesik et al., 2015). The activation of this neuronal network translates into hemodynamic responses through the release of multiple mediators (Hillman, 2014; Lecrux and Hamel, 2016), such as COX-2 metabolites released from activated pyramidal cells (Lacroix et al., 2015).

Brain "on" states such as arousal, attention, and memory involve the activation of acetylcholine (ACh)-releasing basal forebrain (BF) neurons projecting throughout the cerebral cortex. Conversely, phasic reductions in ACh levels are found in slowwave sleep, whereas chronic ACh decreases are associated with pathological conditions such as Alzheimer's disease (AD) (Hasselmo and Sarter, 2011). Experimental increases in ACh levels through acetylcholinesterase (AChE) inhibition or cortical ACh iontophoresis heighten sensory evoked potentials and local field potentials (LFPs), uncover previously silent receptive fields, and facilitate neuronal coding (Metherate et al., 1988; Tremblay et al., 1990; Goard and Dan, 2009). ACh also modulates sensory processing by enhancing the signal strength of incoming thalamocortical afferents relative to intracortical pathways (Oldford and Castro-Alamancos, 2003). When combined with an auditory stimulus, BF activation lowers the response threshold and broadens the receptor field in the auditory cortex (Kilgard and Merzenich, 1998; Chen and Yan, 2007). Increased ACh also enhances odor discrimination and sharpens mitral cell receptive fields in the olfactory bulb, whereas cholinergic lesion decreases odor discrimination (Chaudhury et al., 2009). Similarly, loss of ACh BF neurons is associated with reduced firing rate in all layers of the rat barrel cortex during whisker stimulation (Herron and Schweitzer, 2000).

Surprisingly, despite these recognized interactions between ACh and sensory processing, it is virtually unknown how sensory evoked NVC is affected by altered ACh neurotransmission. Therefore, we sought to determine in vivo the outcomes of changing ACh levels on whisker-evoked NVC, assessing both CBF and neuronal responses through measurements of LFPs (i.e., the amplitude of the evoked response and power in frequency bands). ACh levels were increased to reproduce brain states of attention or arousal or were chronically decreased to mimic the pathological loss of ACh innervation, which is a key feature of AD. The fidelity of NVC was determined by computing LFP/CBF correlations across ACh tones. Further, we interrogated whether changes in ACh levels would alter the neuronal network of pyramidal cells and GABA interneurons typically recruited in the barrel cortex after whisker stimulation using double immunohistochemistry with c-Fos, a marker of neuronal activation (Staiger, 2006). Overall, we demonstrate that whisker-evoked
$\mathrm{CBF}$ and LFP responses are altered as a function of ACh tone. ACh appears to be, not only a facilitator, but also a requirement, for the full expression of the NVC responses to whisker stimulation. Our data suggest that brain levels of ACh alter the fidelity of CBF in reflecting the underlying sensory-evoked neuronal responses.

\section{Materials and Methods}

\section{Experiments}

All experiments were performed on Sprague Dawley male rats (250-400 g, $8-13$ weeks-old, $n=145$ ), were approved by the animal ethics committee of the Montreal Neurological Institute at McGill University, and abided by the Canadian Council on Animal Care. Experimental procedures are summarized in Figure 1.

\section{Animal preparation}

Animals were prepared as described previously (Lecrux et al., 2011) for $\mathrm{CBF}$ experiments. Briefly, rats were anesthetized with urethane $(1.2 \mathrm{~g} / \mathrm{kg}$, i.p.), placed in a stereotaxic frame (Kopf Instruments), and body temperature was maintained at $37^{\circ} \mathrm{C}$. Physiological parameters, measured through a femoral artery catheter (AD Instruments and Rapid Lab 348; Siemens) were within the normal range and remained unchanged within each group during all procedures [pH: 7.40-7.46; $\mathrm{pO}_{2}$ : 82-113 mmHg; $\mathrm{pCO}_{2}: 33-42 \mathrm{mmHg}$; mean blood pressure: $68-100$ $\mathrm{mmHg}$, heart rate (HR): 246-394 bpm]. For combined electrophysiological experiments, rats were ventilated ( $50 \mathrm{bpm}$, medical air), placed in a stereotaxic frame, monitored continuously for physiological parameters $\left(\mathrm{O}_{2}\right.$ saturation: $93-97 \%$; HR: 256-286 bpm), and recordings were performed under medetomidine anesthesia $(0.1 \mathrm{mg} / \mathrm{kg} / \mathrm{h})$ starting $\sim 1 \mathrm{~h}$ after isoflurane was discontinued, as shown previously to be highly suitable for electrophysiological recordings and for NVC studies (Pawela et al., 2009; Williams et al., 2010; Masamoto and Kanno, 2012; Nasrallah et al., 2014; Sotero et al., 2015). For anatomical studies, c-Fos induction was performed in trained ( $5 \mathrm{~d}$ ) awake restrained rats, as described previously (Lecrux et al., 2011).

\section{Cortical blood flow measurement}

$\mathrm{CBF}$ was recorded continuously with a laser-Doppler flowmeter (LDF) microprobe (wavelength: $785 \mathrm{~nm}, 0.58 \mathrm{~mm}$ diameter, $0.5 \mathrm{~mm}$ transmit/ receive spacing; Transonic Systems) positioned above the thinned bone over the left barrel cortex $\left(\sim 6 \mathrm{~mm}^{2}\right.$ centered on bregma coordinates AP: $-3 \mathrm{~mm}$, L: $+6 \mathrm{~mm}$; Fig. $1 A$ ). For combined electrophysiological and CBF experiments, the LDF probe was placed close to the recording electrode insertion point after the dura was removed (Fig. 1A).

\section{Electrophysiology}

Extracellular LFPs were recorded through a 50- $\mu$ m-wide 32-channel electrode (100 $\mu \mathrm{m}$ intersite spacing, electrode site area: $177 \mu \mathrm{m}^{2}$; Neuronexus Technologies; Fig. $1 B$ ) inserted in the barrel cortex (AP: $-3 \mathrm{~mm}$, $\mathrm{L}:+6.5 \mathrm{~mm}$ from the bregma). Neurophysiological data were acquired at $24 \mathrm{kHz}$ using a RZ2 multichannel recording system (Tucker-Davis Technologies).

\section{Whisker stimulation}

For $\mathrm{CBF}$ experiments alone, all whiskers on the right side were deflected by mechanical stimulation (electrical tooth brush, $\sim 8-10 \mathrm{~Hz}, 20 \mathrm{~s}, 7$ trials; Lecrux et al., 2011). For combined electrophysiological and CBF experiments requiring precise synchronization of the stimulus with the electrophysiological responses, whiskers were deflected with an automated air-puff stimulator ( $4 \mathrm{~Hz}, 20$ s, 10 trials; Sanganahalli et al., 2008; Lecrux et al., 2011). For c-Fos induction, rats underwent mechanical whisker stimulation $(\sim 4 \mathrm{~Hz}, 10 \mathrm{~min})$ of the right $\mathrm{C} 1-3$ whiskers, as described previously (Lecrux et al., 2011).

\section{Identification of the neuronal network recruited by whisker stimulation}

Rats prepared for ACh enhancement or depletion (detail below) underwent whisker stimulation and after $1 \mathrm{~h}$ were deeply anesthetized (sodium pentobarbital, $100 \mathrm{mg} / \mathrm{kg}$, i.p.) for perfusion with $4 \%$ paraformaldehyde (PFA) through the ascending aorta. Brains were removed, postfixed in 
PFA $\left(2 \mathrm{~h}, 4^{\circ} \mathrm{C}\right)$, and cryoprotected. After snap freezing, $25-\mu \mathrm{m}$-thick sections were cut on a freezing microtome and immunohistochemically stained for c-Fos (rabbit anti-c-Fos, 1:1500; Santa Cruz Biotechnology) either alone or combined with COX-2 (rabbit anti-COX-2, 1:3000; Santa Cruz Biotechnology), VIP (guinea pig anti-VIP, 1:5000; Peninsula Laboratories), or SOM (rabbit anti-SOM, 1:2000; Peninsula Laboratories) for identification of activated pyramidal cells and GABA interneurons, as described previously (Kocharyan et al., 2008; Lecrux et al., 2011). Immunoreactivity to c-Fos was first detected with the slate gray reagent (SG kit; Vector Laboratories, blue-gray precipitate) and all other antibodies were detected in the second position using 3,3'diaminobenzidine (DAB; Vector Laboratories, brown precipitate). For detection of cortical ACh innervation, freezing microtome $35-\mu \mathrm{m}$ thick sections were immunostained for choline acetyltransferase (ChAT; goat anti-Chat, 1:250; Millipore Bioscience Research Reagents) and the reaction visualized with DAB. Digital photographs from the barrel cortex region were acquired with a Nikon Eclipse E800 camera and edited using Photoshop 7 (Adobe Systems).

\section{Enhanced ACh tone}

To enhance ACh tone pharmacologically, rats received an injection of either $10 \mathrm{mg} / \mathrm{kg}$ intraperitoneal Linopirdine (Tocris Bioscience), an AChrelease enhancing agent (Zaczek et al., 1997), or $0.1 \mathrm{mg} / \mathrm{kg}$ subcutaneous physostigmine hemisulfate (Tocris Bioscience), a specific AChE inhibitor (Bhat et al., 1990; Fig. 1B). Their effects on whisker stimulation were tested 20-30 min after injection and found to be stable after 20-40 $\mathrm{min}$ (see Results). In addition, increase in endogenous ACh levels was achieved using subthreshold (no significant effects on resting $\mathrm{CBF}$ ) $\mathrm{BF}$ electrical stimulation $(30 \mathrm{~s}$, starting $10 \mathrm{~s}$ before whisker stimulation, $100 \mathrm{~Hz}, 0.5 \mathrm{~ms}, 1 \mathrm{~s}$ on/ $1 \mathrm{~s}$ off, $150 \pm$ $30 \mu \mathrm{A}$, isolated pulse stimulator A-M Systems) performed via a monopolar tungsten electrode (FHC) chronically implanted in the BF, as detailed previously (Kocharyan et al., 2008; Lecrux et al., 2012). The specificity of BF electrical stimulation was confirmed by suprathreshold $\mathrm{BF}$ stimulation, which increases cortical CBF (Lecrux et al., 2012).

\section{Pharmacological blockade of ACh receptors}

Nicotinic ACh receptors (nAChRs) were acutely blocked by intracisternal (i.c.) injection of a mixture of the $\mathrm{nAChR}$ antagonists mecamylamine (MEC) and methylycaconitine (MLA) (1 and $0.1 \mathrm{~mm}$, respectively, $3 \mu \mathrm{l}$; $\mathrm{Fu}$ et al., 2014) and their effects on the whisker-evoked CBF response were measured $20 \mathrm{~min}$ after injection (Fig. 1C). Chlorisondamine dichloride (CHL, $12 \mu \mathrm{g} / 5 \mu \mathrm{l}$; gift from Dr. Paul Clarke, Department of Pharmacology, McGill University) was used to block central nAChRs chronically without affecting peripheral nAChRs (Marenco et al., 2000). CHL or saline (controls) was given $(5 \mu \mathrm{l})$ in a unilateral (left) intracerebroventricular injection (coordinates AP: $0.8 \mathrm{~mm}, \mathrm{~L}: 1.4 \mathrm{~mm}$ from bregma, $4.3 \mathrm{~mm}$ below skull surface) in rats under isoflurane anesthesia ( $2 \%$ in medical air). Rats were returned to their cages and used 2-4 weeks later (Fig. 1D). Muscarinic ACh receptors (mAChRs) (Fig. 1C) were blocked with scopolamine ( $3 \mu$ l, i.c., or a $10^{-4} \mathrm{M}$ solution; Tocris Bioscience; Lecrux et al., 2011) and their effects on whisker-evoked CBF responses were monitored $30 \mathrm{~min}$ after injection.

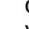
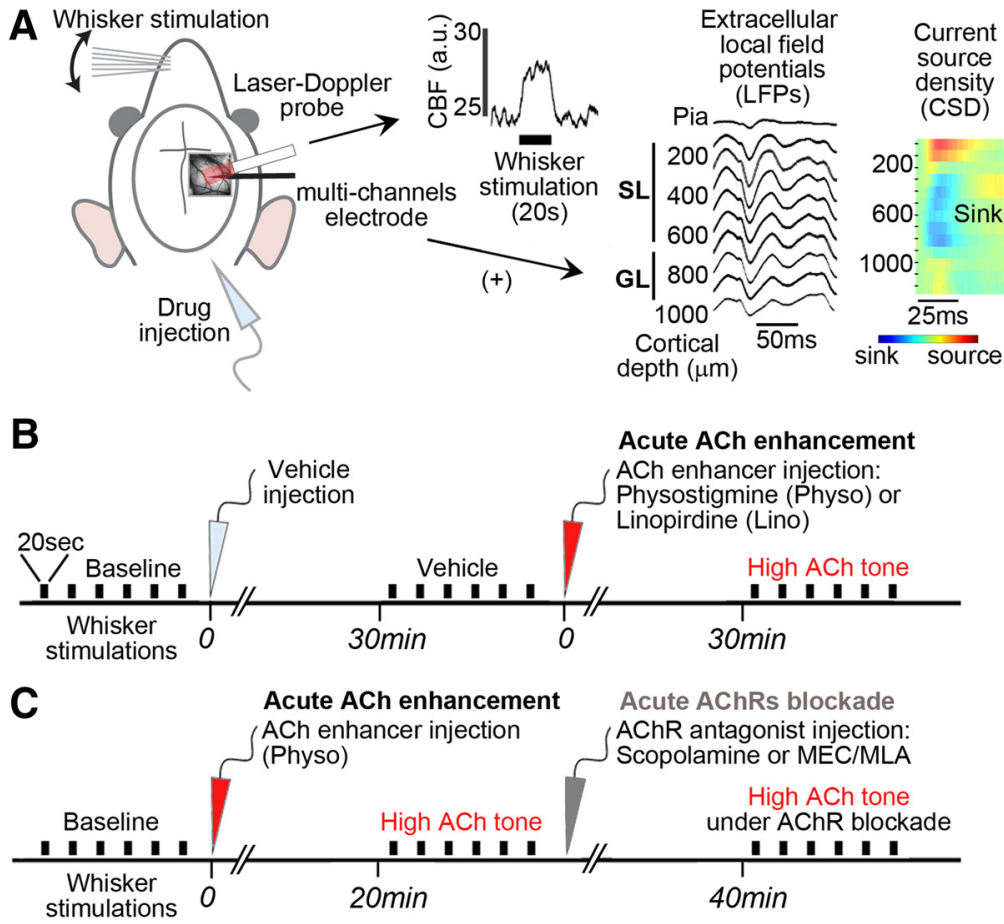

D Chronic nAChRs blockade $\int \mathrm{nAChR}$ antagonist injection:

Chlorisondamine $(\mathrm{CHL})$

as in (B)

E Chronic ACh depletion

(192-IgG Saporin (Saporin)

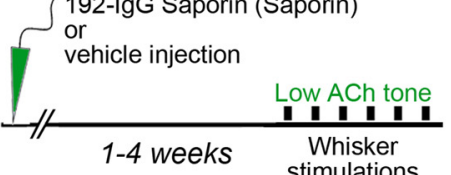

Figure 1. Schematic representation of the experimental procedures. $A$, In the first set of experiments (Fig. 2), cortical CBF was sured by a LDF probe placed over the thinned bone above the barrel cortex, as illustrated on a representative raw trace of a single 20 s whisker stimulation. In a parallel set of experiments (Figs. 3-5), a multicontact linear electrode was added $(+)$ close to the LDF probe. To match the CBF and LFPs data, we analyzed the recordings channels of the electrode in the cortical layers matching responses. $\boldsymbol{B}$, Acute pharmacological ACh enhancement consisted in injections of respective vehicle (light gray arrow), followed by in of ACh enhancers (red arrow): the AChE inhibitor physostigmine (Physo) or the ACh release enhancer Linopirdine (Lino). (scopolamine) or a mixture of nAChR antagonists (MEC/MLA). D, Timeline for chronic blockade of $n A C h R s$ by CHL injected 2-4 C BF testing under enhanced $A C h$ tone, as described above in B.E, For ACh depletion, rats were tested $1-4$ weeks after was tested for only one drug or combination. The electrical BF stimulation protocol is not shown; see Materials and Methods for further details. Black bars indicate $20 \mathrm{~s}$ of whisker stimulation (six to 10 trials per condition). a.u., Arbitrary unit.

\section{Decreased ACh tone}

For ACh depletion, rats were anesthetized with isoflurane (5\% for induction, $2 \%$ for maintenance) and received a unilateral intracerebroventricular injection ( $2 \mu \mathrm{l}$; coordinates as above) of the selective cholinotoxin 192-IgG-saporin (4 $\mu \mathrm{g} / 2 \mu \mathrm{l}$; Advanced Targeting Systems) or saline (control rats), as described previously (Kocharyan et al., 2008). Rats were returned to their cages and used 1-4 weeks later (Fig. 1E).

\section{Data analysis}

Hemodynamic signals. CBF values were acquired as LDF arbitrary units, averaged every second, and expressed as percentage change relative to the 20 s prestimulation. Resting CBF values were obtained from averaged 1 min segments before each whisker stimulation block (Table 1).

Electrophysiological data alignment. Cortical layers matching the depth of penetration of LDF ( $\sim 1 \mathrm{~mm}$; Fredriksson et al., 2009) were defined from the pial surface as follows: superficial layer (SL; 200-600 $\mu \mathrm{m})$ and granular layer (GL; 700-900 $\mu \mathrm{m}$ ), based on previous studies (Ren et al., 1992; Herron and Schweitzer, 2000) and our own histology findings. In some rats $(n=5)$, we imaged the microelectrode during insertion to localize the microelectrode contacts relative to the pial surface (Sotero et 
Table 1. Baseline CBF values

\begin{tabular}{|c|c|c|c|}
\hline & $\begin{array}{l}\text { Resting CBF } \\
\text { (a.u.) }\end{array}$ & $\begin{array}{l}\text { Repeated-measures } \\
\text { ANOVA Newman-Keuls } \\
\text { post test }\end{array}$ & $n$ \\
\hline \multicolumn{4}{|l|}{ CBF studies } \\
\hline Baseline & $16.0 \pm 2.4$ & n.s. & 7 \\
\hline + Vehicle & $14.8 \pm 2.2$ & & \\
\hline + Linopirdine, i.p. & $13.8 \pm 2.4$ & & \\
\hline Baseline & $15.1 \pm 2.2$ & n.s. & 5 \\
\hline + Vehicle & $20.0 \pm 4.3$ & & \\
\hline + Physostigmine, s.c. & $20.2 \pm 2.9$ & & \\
\hline Baseline & $15.3 \pm 1.2$ & & 9 \\
\hline BF stimulation alone & $15.8 \pm 1.5$ & n.s. & \\
\hline + BF stimulation & $16.0 \pm 1.6$ & & \\
\hline \multicolumn{4}{|l|}{ Chlorisondamine vehicle, i.c.v. } \\
\hline Baseline & $20.2 \pm 2.3$ & n.s. & 5 \\
\hline + Vehicle & $19.5 \pm 2.2$ & & \\
\hline + Physostigmine, s.c. & $22.7 \pm 2.1$ & & \\
\hline \multicolumn{4}{|l|}{ Chlorisondamine, i.c.v. } \\
\hline Baseline & $22.9 \pm 2.9$ & n.s. & 7 \\
\hline + Vehicle & $23.0 \pm 3.9$ & & \\
\hline + Physostigmine, s.c. & $26.3 \pm 5.2$ & & \\
\hline Baseline & $13.6 \pm 1.1$ & & 6 \\
\hline + Physostigmine, s.c. & $17.3 \pm 2.5] *$ & & \\
\hline+ MEC/MLA, i.c. & $14.4 \pm 1.7$ & & \\
\hline Baseline & $22.6 \pm 4.0$ & n.s. & 7 \\
\hline + Physostigmine, s.c. & $27.8 \pm 5.4$ & & \\
\hline + Scopolamine, i.c. & $25.9 \pm 5.4$ & & \\
\hline Baseline & $19.7 \pm 3.4$ & n.s. & 5 \\
\hline + Vehicle & $16.7 \pm 2.1$ & & \\
\hline + Scopolamine, i.c. & $17.5 \pm 2.5$ & & \\
\hline Saporin vehicle, i.c.v. & $17.8 \pm 2.4$ & n.s. & 8 \\
\hline Saporin, i.c.v. & $16.4 \pm 2.6$ & Unpaired $t$ test & 9 \\
\hline \multicolumn{4}{|c|}{$\begin{array}{l}\text { Combined CBF and electrophysiological } \\
\text { studies }\end{array}$} \\
\hline Vehicle & $23.3 \pm 8.3$ & n.s. & 8 \\
\hline + Physostigmine, s.c. & $35.7 \pm 12.6$ & Paired $t$ test & \\
\hline Saporin vehicle, i.c.v. & $31.6 \pm 5.0$ & n.s. & 10 \\
\hline Saporin, i.c.v. & $34.1 \pm 5.5$ & Unpaired $t$ test & 9 \\
\hline
\end{tabular}

Prestimulation CBF values were averaged for each condition during either CBF measurements or combined CBF and electrophysiological recordings. Data were analyzed by repeated measurements ANOVA followed by NewmanKeuls post test or Student's $t$ test as indicated. ${ }^{*} p<0.05$ versus baseline. Values are expressed as mean \pm SEM. a.u., Arbitrary units; i.c., intracisternal; i.c.v., intracerebroventricular; i.p., intraperitoneal; n.s., not significant.; s.c., subcutaneous.

al., 2015). The evoked LFP spectra as a function of depth relative to the pial surface in these animals were then used to guide alignment of the entire dataset. Layer delineation was further confirmed based on individual current source density (CSD) profiles for each rat by identifying major current sources and sinks within the cortical layers (Fig. $1 A$ ), with the major current sinks corresponding to SL and GL, as described previously (Martindale et al., 2003; Jones et al., 2004). CSD was calculated on the first evoked response using the standard 5-point $([1,0,-2,0,1] / 4)$ CSD estimation kernel (Freeman and Nicholson, 1975) and the estimation at the edge electrodes was computed using the method of Vaknin (Vaknin et al., 1988).

Electrophysiological signals. Analysis of neurophysiological data was performed using scripts in MATLAB (The MathWorks). Data were filtered $(1-500 \mathrm{~Hz})$ and downsampled to $2 \mathrm{kHz}$ to extract LFPs. Then, 250 ms segments time locked to the stimulus $(4 \mathrm{~Hz})$ were averaged over the $20 \mathrm{~s}$ stimulation period to calculate the amplitude of the evoked response, defined as the difference between the maximum (P1) and minimum (N1) amplitude values averaged over recorded channels in SL and GL. LFP spectra, obtained using the multitaper method (http://chronux. org/), were normalized by dividing the stimulation epoch's spectrum by the prestimulus baseline spectrum. Band-pass-filtered LFP signal was squared in each band and normalized (divided by the average power of the final $5 \mathrm{~s}$ of the prestimulus period) to obtain band-limited power.
The following frequency bands were analyzed: theta $(5-8 \mathrm{~Hz})$, alpha $(8-12 \mathrm{~Hz})$, beta $(15-30 \mathrm{~Hz})$, low-gamma $(30-57 \mathrm{~Hz})$, and high-gamma (63-150 Hz). For baseline (prestimulus) neuronal activity, LFP spectra were computed over prestimulation epochs $(20 \mathrm{~s})$ for each condition. LFP power was calculated for low (L: $1-4 \mathrm{~Hz})$ and high $(\mathrm{H}: 20-60 \mathrm{~Hz})$ frequencies in SL and GL using areas under the curve (AUCs) from the $\mathrm{LFP}$ spectra. In addition, the corresponding $\mathrm{L} / \mathrm{H}$ ratio was computed and used as an index of cortical state, as described previously (Li et al., 2009; Pinto et al., 2013; Fazlali et al., 2016). For saporin and vehicle (control) group comparisons, only the $\mathrm{L} / \mathrm{H}$ ratio was used because these conditions were from different animals.

LFP/CBF correlations. The percentage changes in LFP power in selected frequency bands evoked by whisker stimulation were correlated with the concurrent percentage changes in CBF over individual trials, as analyzed previously by us and others (Logothetis et al., 2001; Lauritzen and Gold, 2003; Niessing et al., 2005; Shmuel et al., 2006; Magri et al., 2012; Harris et al., 2014).

Cholinergic denervation. ChAT-immunostained nerve fibers in the somatosensory cortex were ranked on a scale of $0-5$ ( 0 being no visible fibers and 5 being the highest fiber density) on digital photographs from the barrel cortex region ( 3 sections/rat, $n=4$ rats/group) by 2 independent observers blinded to the identity of the photographs. Density rankings were then averaged by animal and by group.

c-Fos immunostaining in the barrel cortex. Quantitative analysis of the c-Fos-immunostained barrel area was performed on digital photographs using NeuroLucida software (MBF Bioscience) to trace the area occupied by c-Fos-positive nuclei in layer IV of the barrel and NeuroExplorer (Nex Technologies) to quantify the corresponding cortical area. For analysis of the rostrocaudal extent of c-Fos-immunostained nuclei, every third section was stained for c-Fos throughout the entire barrel cortex. Sections were observed under light microscopy (Leitz Aristoplan; Leica) and matched to their corresponding bregma levels (Paxinos and Watson, 1998).

Identification of c-Fos-immunopositive neurons in the activated barrel cortex. Two to three double-immunostained sections/rat were observed by light microscopy and cells counted in layers II/III and IV of the labeled barrel. For each cell type, cells that costained for c-Fos were counted and expressed as a percentage of the total number of COX-2, VIP, or SOM cells. For each rat, an average of $634 \pm 44$ cells were counted for COX-2, $243 \pm 14$ for VIP, and $246 \pm 21$ for SOM. Data from the ipsilateral barrel cortex were subtracted from those of the contralateral barrel to obtain the population of cells specifically activated by whisker stimulation.

Statistical analysis. Repeated-measures ANOVA followed by post hoc Newman-Keuls comparison tests or Student's paired $t$ tests were used to compare physostigmine or linopirdine data with their respective controls. Control and saporin-lesioned rats were compared by Student's unpaired $t$ test. Student's $t$ tests of LFP power across frequency bands and cortical layers were corrected for multiple comparisons using the false discovery rate-controlling procedure by Benjamini-Hochberg. LFP/CBF correlations were computed using Pearson's coefficient $(r)$. Betweengroup differences in correlation coefficients were studied using the Fisher's $r$-to- $z$ transformation. The slopes of the linear regression models were compared between controls and each treatment group by including an interaction term $\left(\beta_{3} \cdot\right.$ LFP $\cdot$ Group) in a single regression model of combined datasets as follows: $\left(\mathrm{CBF}=\beta_{0}+\beta_{1} \cdot \mathrm{LFP}+\beta_{2} \cdot\right.$ Group $+\beta_{3}$ - LFP - Group). Statistical analyses were performed with GraphPad Prism 4 software and with $R$ (Foundation for Statistical Computing, Vienna, Austria; version 3.2.3).

\section{Results}

\section{ACh alters whisker-evoked CBF responses}

To investigate the modulatory effects of ACh on NVC responses, we selected doses of ACh-promoting drugs and parameters for electrical BF stimulation that exerted no significant effect on resting $\mathrm{CBF}$ (Table 1). The $\mathrm{CBF}$ response evoked by whisker stimulation was significantly larger after increasing ACh tone pharmacologically with the AChE inhibitor physostigmine $(+40.8 \pm 8.1 \%, p<0.01$; Fig. $2 A)$. This effect of physostigmine appeared as early as $20 \mathrm{~min}$ after injection and remained stable for 
A

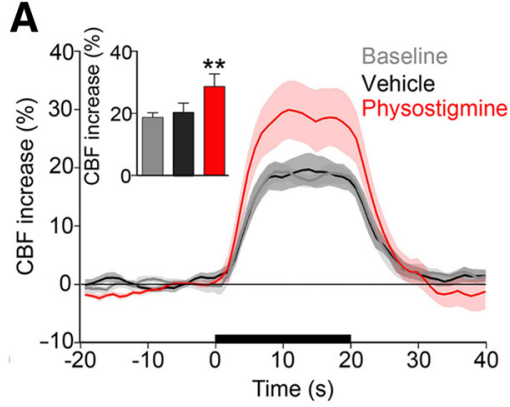

E

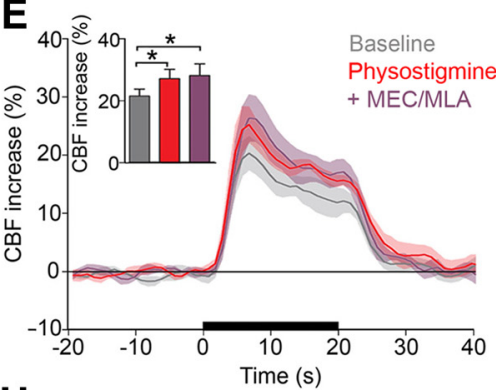

B

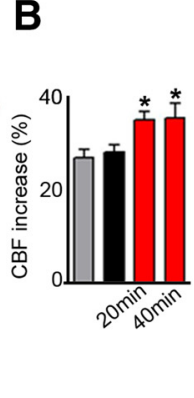

C

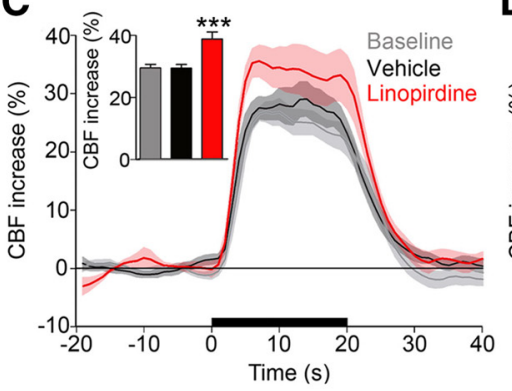

D

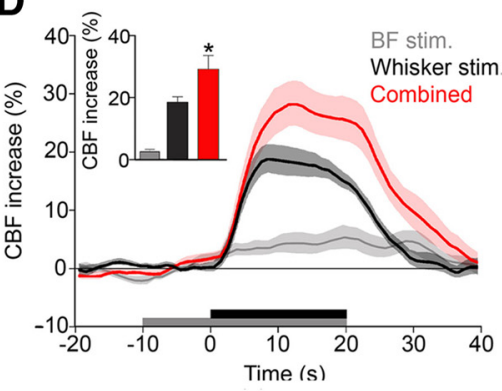

F

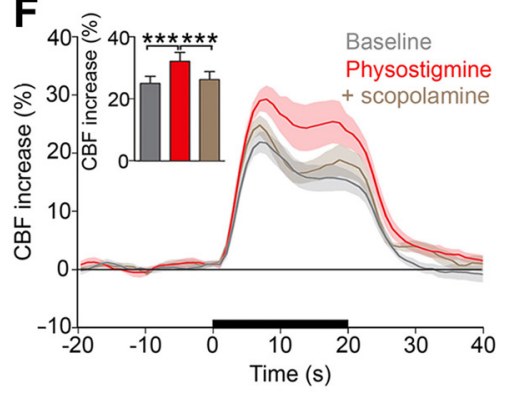

G

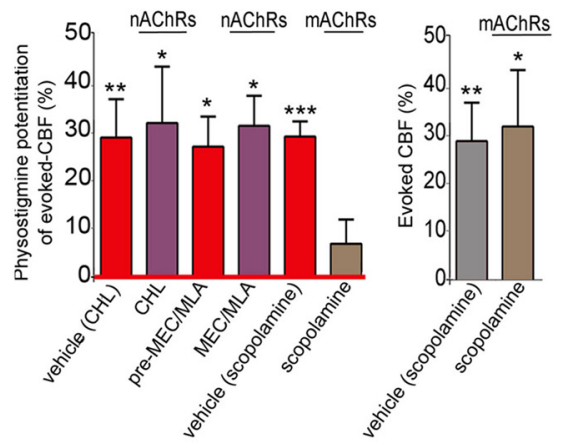

I

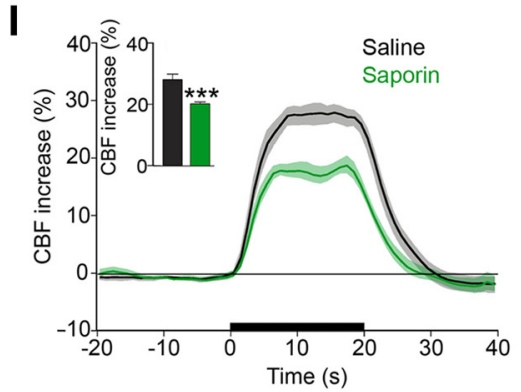

Figure 2. Altered ACh tone affects sensory-evoked CBF responses. Significant potentiation of the evoked (BF response to whisker stimulation (20 s, horizontal black bar) was observed consistently in conditions of increased ACh tone either pharmacologically with physostigmine $(n=5)(\boldsymbol{A})$, tested up to $40 \mathrm{~min}(n=4)(\boldsymbol{B})$, linopirdine $(n=6)(\boldsymbol{C})$, or after subthreshold electrical BF stimulation (30 s, horizontal gray bar; $n=9)(\boldsymbol{D})$. The physostigmine-enhanced (BF-evoked response was not altered by nAChR antagonists administered either acutely (MEC/MLA, $n=6)(\boldsymbol{E})$ or chronically (CHL, $n=7$ compared with vehicle, $n=5)(G) . F$, In contrast, the $m A C h R$ antagonist scopolamine reduced the facilitating effect of physostigmine on the whisker-evoked $(B F$ response significantly $(n=7)(\boldsymbol{G})$ without affecting the (BF response to whisker stimulation alone $(n=5)$. $\boldsymbol{G}$, Antagonist effects expressed as a percentage of potentiation induced by physostigmine after each drug administration. In contrast, reduced cortical ACh innervation with saporin was associated with a significant loss of (hAT-immunostained fibers in the barrel cortex $(\boldsymbol{H})$ and a significantly smaller whisker-evoked CBF response $(I)$ compared with control rats ( $n=8$ and 10, respectively). Scale bar, $20 \mu$ m. Shaded areas represent SEM. ${ }^{*} p<0.05 ;{ }^{* *} p<0.01$ by repeated-measures ANOVA or unpaired $t$ test.

up to $40 \mathrm{~min}(n=4$; Fig. $2 B)$. Similar potentiation of the whiskerevoked CBF response was found with the ACh release enhancer linopirdine $(+30.7 \pm 3.6 \%, p<0.001$; Fig. $2 C)$ and after subthreshold electrical BF stimulation $(+51.9 \pm 18.3 \%, p<0.05$; Fig. 2D). We further evaluated the role of ACh in the potentiated CBF responses by blocking ACh receptors. The potentiating effect of physostigmine on whisker-evoked CBF responses was not altered by acute blockade of nAChRs with a combination of the selective antagonists MEC/MLA $(+26.8 \pm 6.2 \%, p<0.05$, after physostigmine alone vs $+31.1 \pm 11.3 \%$ after MEC/MLA, $p<$ 0.05 ; Fig. $2 E, G$ ) despite a small but significant effect on resting CBF (Table 1). Similarly, chronic blockade of nAChRs with CHL pretreatment did not alter the capacity of physostigmine to enhance the NVC response to whisker stimulation $(+28.7 \pm 7.9 \%$ in physostigmine/vehicle-treated rats, $p<0.01$, vs $+31.7 \pm$ $11.6 \%$ increase in physostigmine/CHL-treated rats, $p<0.05$; Fig. $2 G)$. In contrast, mAChR blockade with scopolamine potently reduced $(>75 \%, p<0.01)$ the facilitating effect of physostigmine on the hyperemic response to whisker stimulation $(+28.9 \pm$ $3.1 \%$ before vs $+7.0 \pm 5.0 \%$ after scopolamine; Fig. $2 F$ ). How- ever, scopolamine did not affect the whisker-evoked CBF response under control condition $(+3.3 \pm 9.4 \%$; Fig. $2 G)$, as was reported previously (Nakao et al., 1999). Conversely, chronic ACh denervation with the selective cholinotoxin saporin, which induced a dramatic loss of ChAT-immunostained ACh fibers in the barrel cortex $(\sim 70 \%, p<0.001$; Fig. $2 H)$, resulted in a significant decrease in the CBF response evoked by whisker stimulation $(-40.7 \%, p<0.001$; Fig. $2 I)$. These findings demonstrate that $\mathrm{ACh}$, through $\mathrm{mAChRs,} \mathrm{enhances} \mathrm{the} \mathrm{CBF} \mathrm{responses} \mathrm{evoked}$ by whisker stimulation. Further, they unveil the prerequisite of the ACh input for an optimal whisker-evoked CBF response.

\section{High ACh tone increases whisker-evoked neuronal activity in} the barrel cortex

To determine whether the increased whisker-evoked CBF response under high ACh tone resulted from increased cortical activity, we recorded whisker-evoked CBF and LFPs simultaneously using an intracortical linear multichannel electrode (Fig. $1 A$ ). We first confirmed the enhancing effect of physostigmine injection on the hyperemic response to whisker stimulation 
A
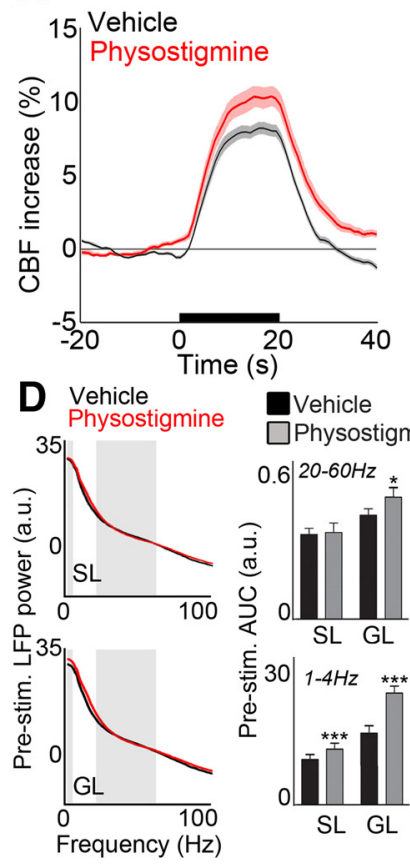

B

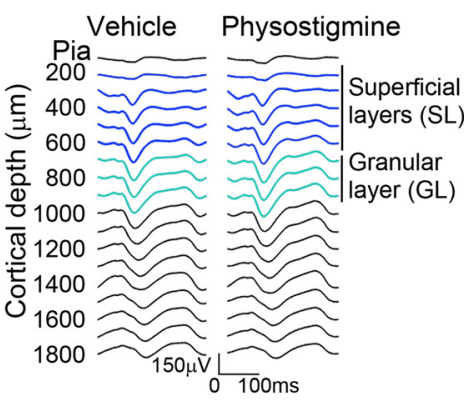

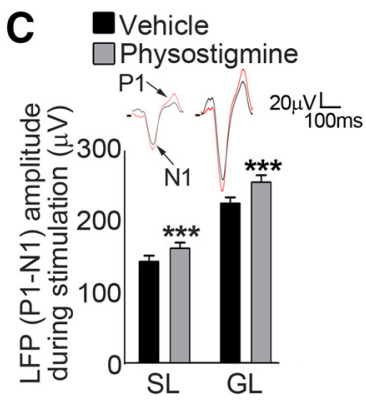

$\mathbf{F}$

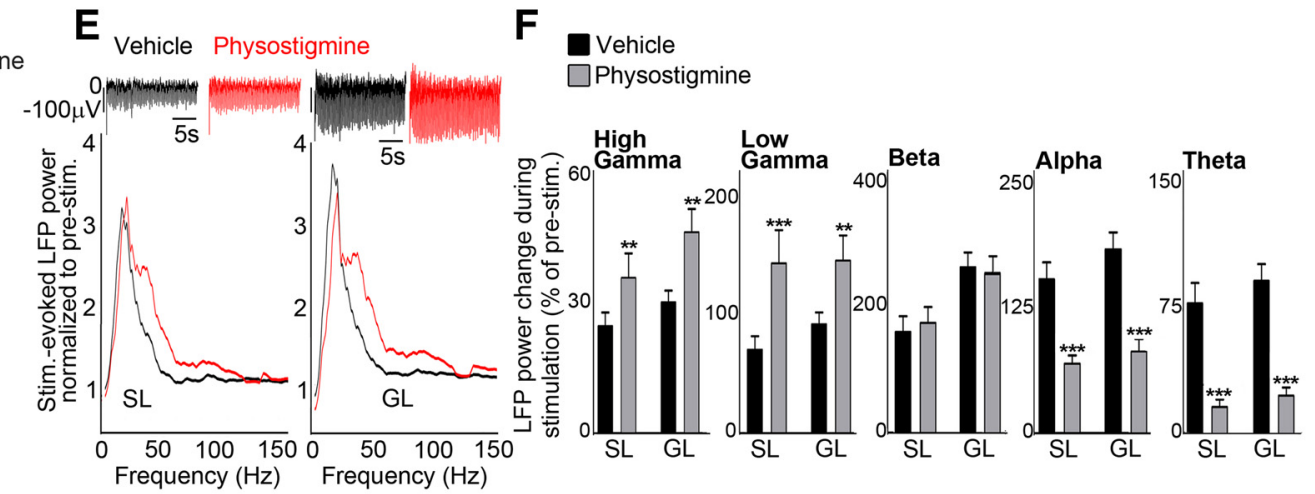

G
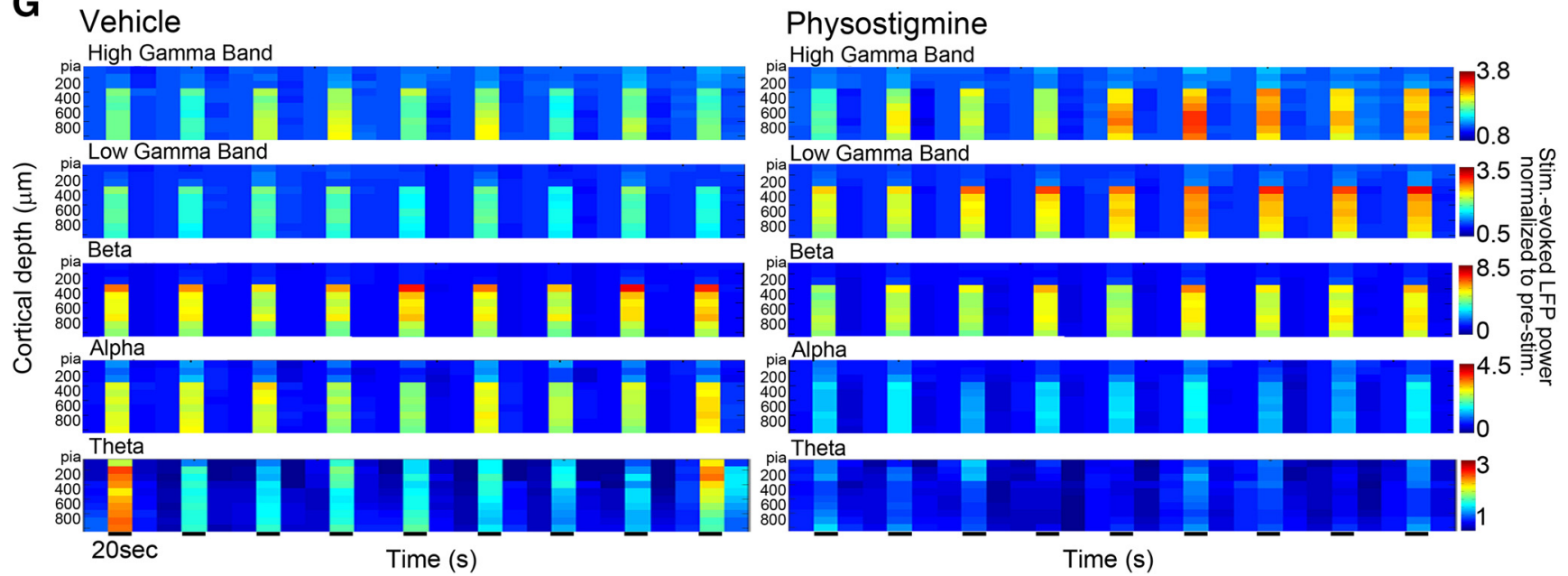

Figure 3. Increased sensory-evoked (BF responses mirror increases in neuronal activity. $\boldsymbol{A}$, Increased whisker-evoked-CBF responses by enhanced ACh tone (physostigmine) matched (B) increased of LFP evoked responses across cortical layers, delineated as the SL and GL layers and quantified by LFP (P1-N1) amplitude (C). Insets show averaged SL and GL evoked responses. D, Physostigmine altered the averaged baseline LFP power in SL (top) and GL (bottom), as quantified by the AUCs of the LFP spectra for high frequencies $(20-60 \mathrm{~Hz})$ and low frequencies ( $1-4 \mathrm{~Hz})$, as indicated by gray boxes. $\boldsymbol{E}$, Raw LFPs during stimulation (top) were increased by physostigmine in SL and GL. The normalized LFP spectra (bottom) further show shift of frequencies under enhanced ACh tone by physostigmine during sensory stimulation in both SL and GL. F, Power change during stimulation (as a percentage from baseline) in high-gamma (63-150 Hz) and low-gamma ( $30-57$ $\mathrm{Hz}$ ) bands showed a clear increase in all layers compared with control (vehicle). In contrast, the beta $(15-30 \mathrm{~Hz})$ band displayed no alteration of its power and power in lower-frequency bands [alpha $(8-12 \mathrm{~Hz})$ and theta $(5-8 \mathrm{~Hz})]$ decreased. $\mathbf{G}$, Averaged band-limited power in selected frequency bands as a function of cortical depth for repeated trials $(20 \mathrm{~s}$ baseline/prestimulation, $20 \mathrm{~s} 4 \mathrm{~Hz}$ whisker stimulation, $20 \mathrm{~s}$ poststimulation) in both control and physostigmine conditions. All data are shown as group averages. $n=78$ and 67 trials for control and physostigmine conditions, respectively, from 8 rats. ${ }^{* *} p<0.01 ;{ }^{* * *} p<0.001$, Student's paired $t$ test: physostigmine versus control (vehicle). a.u., Arbitrary unit; Stim, whisker stimulation.

$(+27.8 \%, p<0.001$; Fig. $3 A)$ under medetomidine anesthesia, demonstrating the robustness of the physostigmine effect on the evoked-CBF response. Concomitant to the larger evoked-CBF responses, physostigmine potentiated the amplitude of the evoked LFPs significantly in both SL $(+13.1 \%, p<0.001)$ and $\mathrm{GL}(+12.6 \%$, $p<0.001$ ) of the contralateral barrel cortex (Figs. $3 B, C$ ).

A nonselective significant broadband increase of the prestimulation neuronal activity was seen after physostigmine injection, as shown on the LFP spectra (Fig. 3D, left) and quantified AUC in high (H: $20-60 \mathrm{~Hz})$ and low (L: $1-4 \mathrm{~Hz})$ frequencies in both SL and GL (Fig. 3D, right). This was also reflected in the $\mathrm{L} / \mathrm{H}$ ratio, which significantly increased in GL (vehicle: $34.9 \pm 2$, physostigmine: $52.7 \pm 3, p<0.001$ ), but not in SL (vehicle: $33.6 \pm 2$, physostigmine: $31.5 \pm 2$ ). These effects mimic previously documented increases in low and high EEG frequencies upon pharmacological (NMDA-induced) activation of the BF (Cape et al., 2000), but contrast with the desynchronization observed upon fast optogenetic activation of ACh neurons (Pinto et al., 2013; Kalmbach and Waters, 2014).

After physostigmine injection, whisker-evoked raw LFPs (Fig. $3 E$, top) and LFPs normalized to baseline (prestimulation) levels (Fig. 3E) increased markedly. The averaged normalized LFP spectra 
in SL and GL showed a clear shift of stimulus-evoked LFP power toward higher frequencies (Fig. $3 E$ ). When decomposing the LFP signals in frequency bands (Figs. $3 E-G$ ), physostigmine-treated rats exhibited increases in both the high-gamma (SL: $+17.4 \%, p<0.01$ and GL: $26.4, p<0.01$ ) and low-gamma (SL: $+43.3 \% p<0.001$ and GL: $+23.6 \%, p<0.01)$ bands. These increases were highly selective because lower-frequency bands remained unaltered (beta) or decreased (alpha: SL: $-54.8 \%, p<0.001$ and GL: $-55.5 \%, p<0.001$, and theta: SL: $-78.3 \%, p<0.001$ and GL: $-74.1 \%, p<0.001)$. Moreover, these effects were found consistently over repeated stimulations (Fig. 3G), highlighting the robust modulatory effect of ACh on the evoked responses. Overall, a high ACh tone induced changes in whisker-evoked LFPs across cortical layers that involved a shift of the evoked LFP spectrum toward higher power in high-frequency oscillations and lower power in the lowest frequencies, suggesting that gamma oscillations drive the ACh-mediated potentiation of the whisker-evoked $\mathrm{CBF}$ responses.

\section{Chronic low ACh tone reduces whisker-evoked neuronal activity in the barrel cortex}

To better understand the underlying mechanisms of ACh depletion on the impaired evoked-CBF response, we combined recordings of CBF and LFPs (Fig. 1A) in control saline-injected rats and in saporin-treated rats. Under medetomidine anesthesia, the reducing effect of $\mathrm{ACh}$ depletion on the $\mathrm{CBF}$ response to whisker stimulation remained robust $(-40.7 \%, p<0.01$; Fig. $4 A)$ and the amplitude of the stimulus-evoked LFPs decreased significantly across cortical layers (SL: $-29.7 \%, p<0.001$, GL: $-12.9 \%, p<$ 0.05 ; Figs. $4 B, C$ ). Baseline LFP power was altered selectively by saporin, as shown by a significantly increased $\mathrm{L} / \mathrm{H}$ power ratio only in GL (Fig. 4D, right). This result is consistent with the increased low-frequency activity reported in resting $\mathrm{AD}$ patients (Montez et al., 2009). During whisker stimulation, ACh depletion resulted in an overall reduction in raw evoked-LFPs (Fig. 4E, top) and in the normalized power of the evoked LFPs across frequencies and cortical layers, except for the theta range (Fig. $4 E$, bottom). In particular, ACh depletion resulted in a potent reduction of band-limited power (Fig. $4 F$ ), consistent across trials (Fig. $4 G$ ), in the high-gamma (SL: $-53.1 \%, p<0.001$ and GL: $-47.2 \%, p<0.001$ ), low-gamma (SL: $-51.2 \%, p<0.001$ and GL: $-36 \%, p<0.001$ ), alpha (SL: $-40.7 \%, p<0.001$ and GL: $-33.2 \%, p<0.05)$ and beta (SL: $-52.0 \%, p<0.001$ and GL: $-34.4 \%, p<0.001)$ frequency bands. In contrast, power in the theta range increased in all layers studied (SL: $+134.2 \%, p<$ 0.001 and GL: $+270.8 \%, p<0.001$; Figs. $4 F, G)$.

\section{Impact of ACh on NVC measured by LFP/CBF correlations}

We investigated the integrity of NVC as a function of ACh tone by computing the correlations between whisker-evoked neuronal activity, defined by LFP power in different frequency bands, and concomitant CBF responses. In the GL of the control group, NVC was better defined by higher frequencies of the LFPs, as illustrated by positive correlations between evoked CBF responses and LFP power in the high-gamma (Fig. $5 A$ ) and low-gamma (Fig. 5B) bands compared with lower frequencies (theta band; Fig. $5 C$ ). In the SL, NVC was defined by a similar pattern, although correlations did not reach significance (Fig. 5D). Under high ACh tone, NVC was improved, as shown by consistent correlations between power in LFP frequency bands and CBF and significantly higher correlation in the high-gamma range (Fig. $5 A, D$ ). In contrast, NVC was significantly disturbed in low ACh tone, as shown by the significant changes in the slopes of the correlations between $\mathrm{CBF}$ and high-gamma $(p<0.05)$, low-gamma $(p<0.05)$, beta and theta bands $(p<0.001)$ in SL and with the high-gamma $(p<$ $0.001)$ and theta $(p<0.05)$ bands in GL (Fig. $5 D)$ compared with control conditions. ACh-depletion-induced alterations of NVC were further depicted by negative correlation (theta band; Fig. $5 C$ ) or lack of correlation in most frequency bands in both the SL and GL (Fig. 5D). Such changes in the LFP/CBF correlations imply that, for an equivalent evoked CBF response, a smaller change in LFP power in the beta and low-gamma bands is required under high ACh tone compared with baseline ACh tone, whereas a significantly larger change in LFP power is needed in ACh-deficient brains. Interestingly, in the high-gamma range, both acute increase and chronic decrease of ACh tone resulted in increased measures of NVC, as illustrated by steeper slopes of the correlations compared with controls (Fig. 5A). However, outcomes were strikingly different: in the enhanced ACh condition, it potentiated the evoked-CBF responses (Fig. $3 A$ ), whereas in the chronically deprived $\mathrm{ACh}$ condition, it failed to drive optimal evoked-CBF responses (Fig. 4A).

\section{Enhanced ACh tone does not alter the neuronal network recruited by whisker stimulation}

To assess whether the enhanced CBF and LFPs responses observed under increased ACh tone reflected changes in the size or in the identity of the neuronal populations recruited by whisker stimulation, we used the cellular resolution of c-Fos immunohistochemistry as a marker of neuronal activation (Staiger et al., 2000; Kocharyan et al., 2008; Lecrux et al., 2011). A characteristic map of c-Fos-positive neurons, predominantly localized in layer IV of the contralateral activated barrel cortex, was observed in saline-injected rats upon whisker stimulation (Fig. 6A). Neither this map nor the extent of the activated barrel was altered by enhanced ACh tone induced by physostigmine or linopirdine (Fig. 6A). In addition, to test whether increased ACh transmission resulted from the recruitment of cholinoceptive neurons that are not activated by whisker stimulation alone, we performed double immunohistochemistry of c-Fos and specific markers of neuronal populations. Whisker stimulation typically induced activation of COX-2 pyramidal cells and of GABA interneurons containing VIP, with activation of a smaller population of SOM-containing GABA interneurons (Fig. $6 B$ ). This pattern of neuronal activation was not altered after increasing ACh tone with linopirdine (Fig. 6B). Together with the electrophysiological results, these findings indicate that the facilitating effects of ACh on the whisker-evoked CBF responses resulted from increased activity in the typical network of pyramidal cells and GABA interneurons processing sensory information.

\section{Decreased ACh tone reduces the neuronal network recruited by whisker stimulation}

ACh denervation induced a significant reduction in the rostrocaudal extent of the activated barrel cortex occupied by c-Fos immunostained neurons $(-25 \%, p<0.01$; Fig. $7 A, B)$ and reduced the average barrel area of c-Fos-positive neurons in layer IV $(-39 \%, p<0.05$; Fig. $7 C)$. However, the proportions of specifically activated (c-Fos positive) COX-2 pyramidal cells and GABA interneurons did not change compared with control rats, with a significant proportion of VIPcontaining GABA interneurons being recruited with few activated SOM-containing GABA interneurons (Fig. 7D). These findings indicate that the hampered whisker-evoked CBF and LFPs responses observed after ACh depletion result from a lower number of activated neurons in the network typically recruited by whisker stimulation. 
A
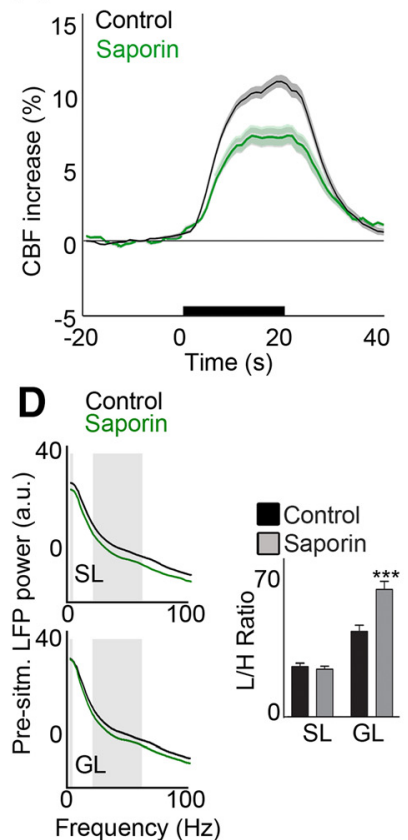

G Control
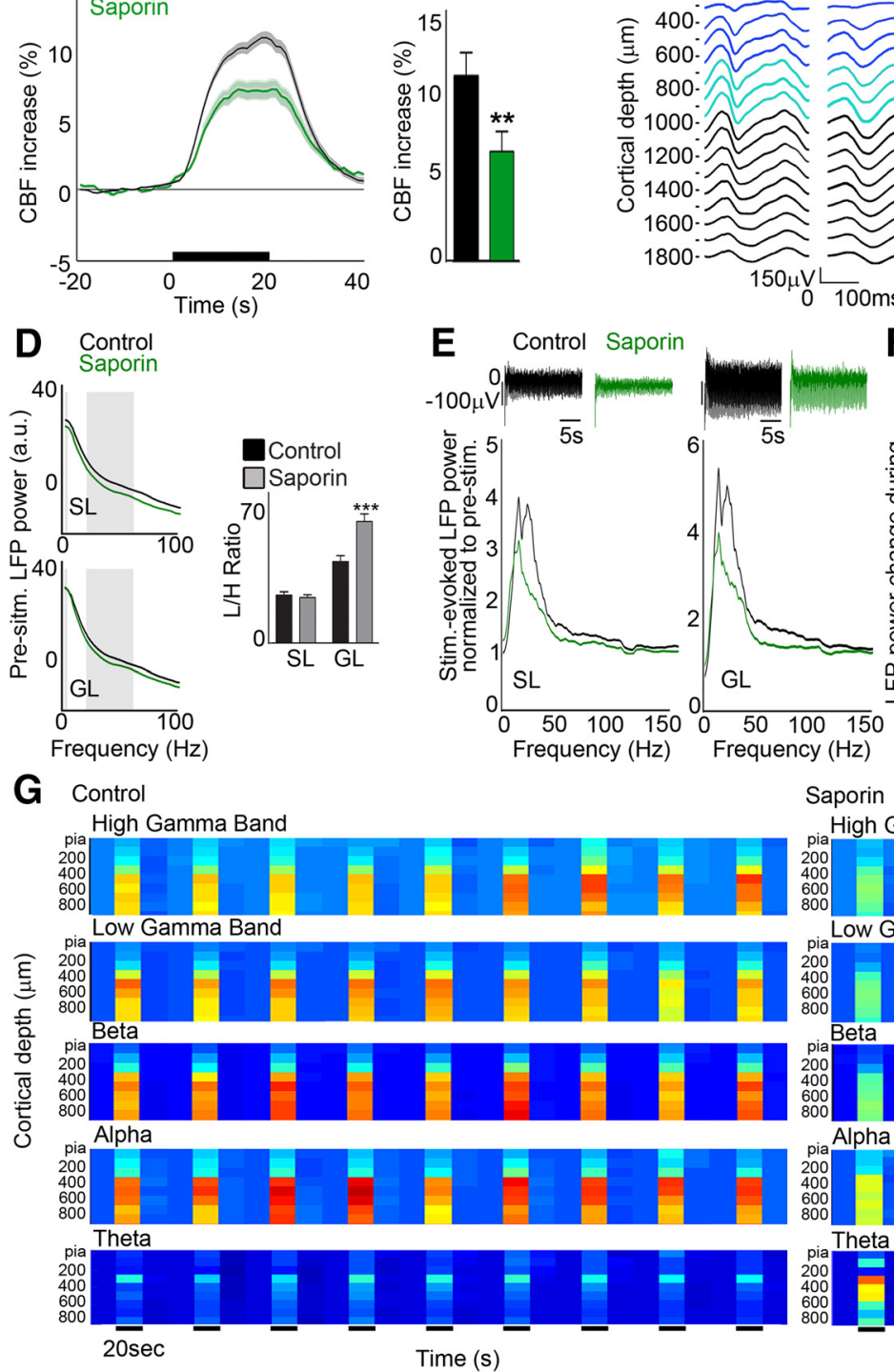
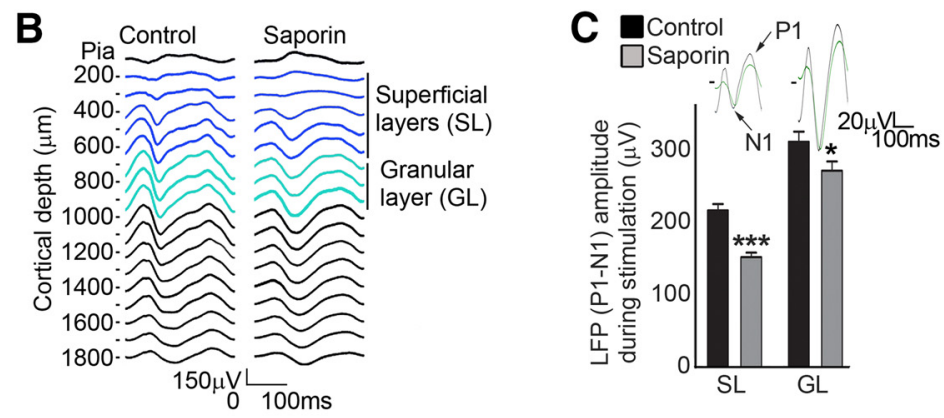

F Control

$\square$ Sapo

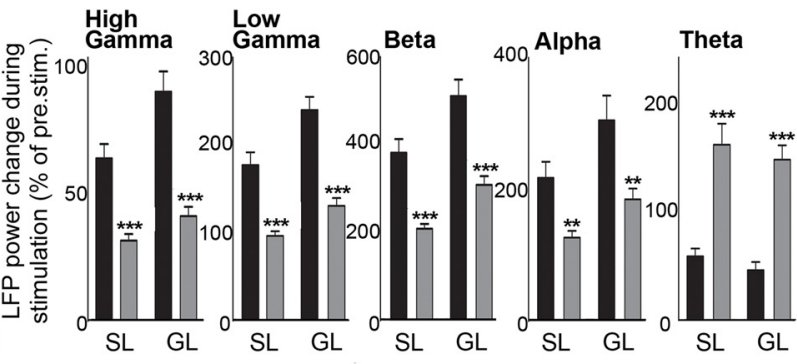

Saporin

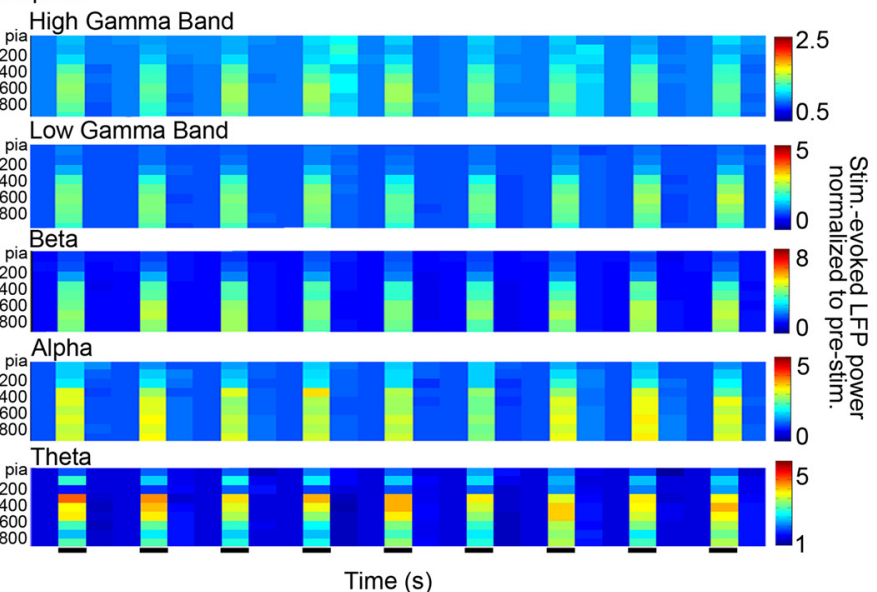

Figure 4. Decreased sensory-evoked CBF responses are associated with decreases in neuronal activity. After saporin treatment, whisker-evoked CBF $(A)$ and LFP $(B, C)$ responses were altered significantly compared with saline-injected (control) animals, as seen by the averaged $250 \mathrm{~ms}$ evoked responses $(\boldsymbol{B})$ and the corresponding LFP amplitude $(\boldsymbol{C})$ in cortical SL and GL layers. D, Saporin altered baseline (prestimulus) neuronal activity in GL, as shown by the LFP L/H ratio computed over low (1- $4 \mathrm{~Hz})$ and high ( $20-60 \mathrm{~Hz})$ frequencies (gray boxes). $\boldsymbol{E}$, Raw LFPs during stimulation (top) were decreased in SL and GL after saporin treatment. Similarly, the LFP spectrum (normalized by baseline) shows overall reduced power of evoked-LFP in ACh-depleted rats. $\boldsymbol{F}$, Decreases in stimulus-evoked band-limited power responses (as a percentage change upon whisker stimulation) in ACh-depleted rats were significant in all cortical layers for high-gamma $(63-150 \mathrm{~Hz})$ and low-gamma $(30-57 \mathrm{~Hz})$, beta $(15-30 \mathrm{~Hz})$, and alpha $(8-12 \mathrm{~Hz})$ frequency bands. In contrast, lower-frequency power increased, as seen in the theta band $(5-8 \mathrm{~Hz}) . \mathbf{G}$, Averaged changes of normalized band-limited power as a function of cortical depth across trials $(20 \mathrm{~s}$ baseline/prestimulation, $20 \mathrm{~s} 4$ Hz whisker stimulation, $20 \mathrm{~s}$ poststimulation) in both control and saporin-treated rats. All data are shown as group averages. $n=84$ trials from 10 rats (controls) and $n=74$ for $n=$ 9 rats (saporin). ${ }^{*} p<0.05 ;{ }^{* *} p<0.01 ;{ }^{* *} p<0.001$ : saporin versus control. a.u., Arbitrary unit; Stim, whisker stimulation.

\section{Discussion}

The present study demonstrates that ACh is not only a facilitator of the whisker-evoked NVC response, but also a prerequisite for its full expression (Fig. 8). Enhanced ACh tone potentiated whisker-evoked $\mathrm{CBF}$ responses through $\mathrm{mAChRs}$ and increased activity within the neuronal network processing sensory information without altering its size or cellular identity. In contrast, chronic decrease in ACh tone reduced whisker-evoked CBF responses and activity dramatically within the recruited neuronal network, reflecting a smaller sensory map representation within the activated barrel. These potent effects were beyond those on baseline activity or hemodynamics because varying ACh tone affected prestimulus neuronal activity differentially with- out altering concomitant CBF responses and all stimulus-induced changes were based on normalized evoked-LFP and evoked-CBF values. Finally, sensory-evoked NVC, defined by LFP/CBF correlations, was improved under enhanced $\mathrm{ACh}$ tone, but impaired in the deficient $\mathrm{ACh}$ condition. We conclude that a basal tone of $\mathrm{ACh}$ is required for cortical neuronal networks processing sensory information to be activated optimally and transduce hemodynamic responses.

$\mathrm{ACh}$ as a facilitator of NVC responses to whisker stimulation The robust potentiation by ACh of the whisker-evoked CBF responses was replicated under various ACh-enhancing manipulations and anesthetic agents and was severely compromised by the 
A

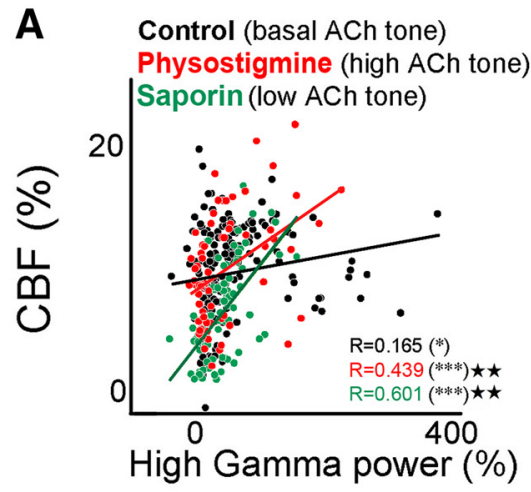

B

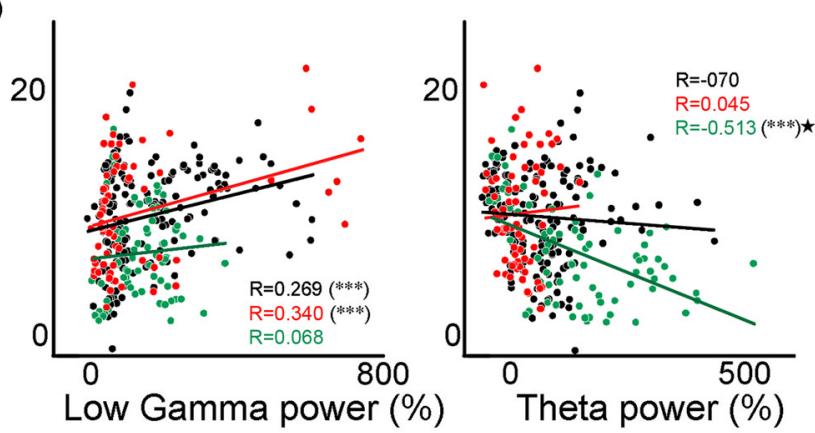

D

\begin{abstract}
Control (basal ACh tone)
Physostigmine (high ACh tone)

Saporin (low ACh tone)
\end{abstract}
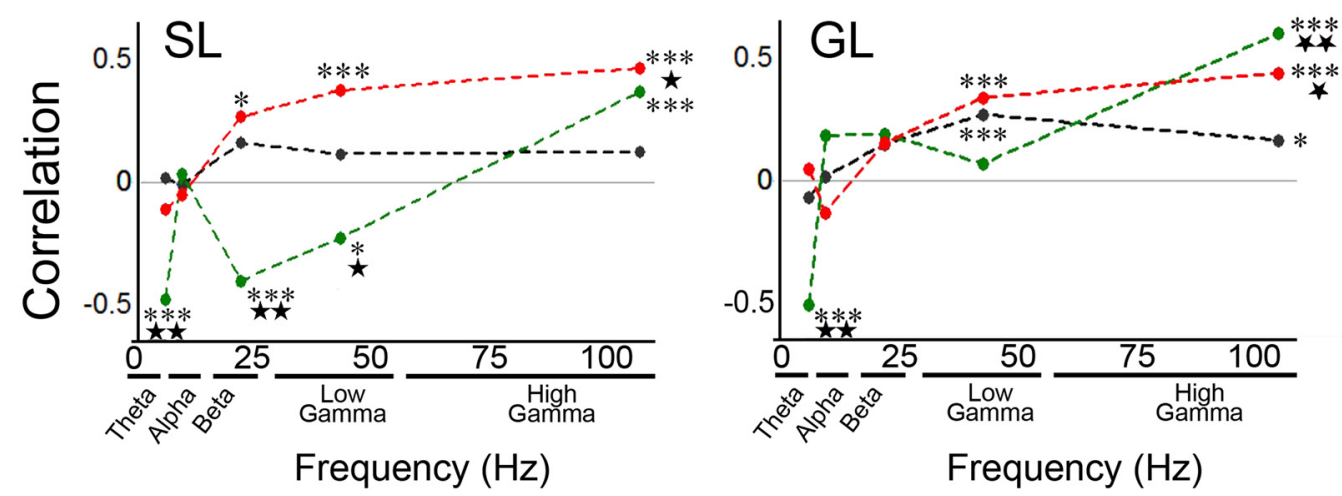

Figure 5. Correlations between electrophysiological (LFP) and hemodynamic (CBF) signals as a function of frequency band and ACh tone. In GL, CBF changes during whisker stimulation were significantly and positively correlated (r: Pearson's coefficient) with the concomitant changes in high- and low-gamma power $(\boldsymbol{A}, \boldsymbol{B})$ under control (black, saline-injected rats), enhanced (red, physostigmine), and low (green, saporin) ACh tone. In the theta band $(\boldsymbol{C})$, the saporin group displayed a significant negative correlation and a slope significantly different from controls, whereas correlations were not significant for the other ACh conditions. $D, C B F / L F P$ correlations as a function of the power of LFP in given frequency band and of ACh tone. Individual symbols represent individual trials $(\boldsymbol{A}-\boldsymbol{C})$ or Pearson's coefficients between $\left(B F\right.$ and the power of the given frequency band for each group $(\boldsymbol{D}) .{ }^{*} p<0.05 ;{ }^{* * *} p<0.001$ for Pearson's $r$ and ${ }^{*} p<0.05 ;{ }^{* * *} p<0.001$ for either slope comparison test $(\boldsymbol{A}-\boldsymbol{C}$ ) or for Fisher's $r$-to-z transformation for between-group differences in correlation coefficients $(\boldsymbol{D})$ compared with controls. Saporin ( $n=74$ from 9 rats), controls ( $n=161$ from 18 rats), and physostigmine ( $n=67$ from 8 rats).

mAChR antagonist scopolamine. A role for mAChRs agrees with previously reported increases in the sensory-evoked hemodynamic maps upon mAChR activation (Penschuck et al., 2002) and decreases in mAChR knock-out mice (Groleau et al., 2014). Although ACh can dilate microvessels through M5 mAChR (Elhusseiny and Hamel, 2000; Yamada et al., 2001), these receptors have a very low level of expression in the cortex and do not modulate cortical activity (Gulledge et al., 2009). We thus conclude that the potentiated hemodynamic responses result from interactions between $\mathrm{ACh}$ and the neuronal network recruited by thalamocortical sensory afferents, rather than direct vascular effects, also consistent with resting CBF remaining largely unaltered across ACh tones (Table 1). Therefore, our findings may provide an underlying mechanism for the documented increased sensory-evoked hemodynamic responses in states of wakefulness and focused attention (Meyer et al., 1991; Peeters et al., 2001; Liu et al., 2013), which involve activation of ACh-releasing neurons (Harris and Thiele, 2011) and mAChR, but not nAChR (Herrero et al., 2008). Accordingly, ACh, mainly through M1 mAChRs (Gulledge et al., 2009; Thiele, 2013), has been shown to enhance the sensitivity of cortical circuits to sensory input by facilitating pyramidal cell spiking (Hasselmo and Sarter, 2011; Nuñez et al., 2012) and interneuron networks (Chen et al., 2015), and AChdriven attentional modulation is largely independent of nAChRs (Hasselmo and Sarter, 2011). We found that enhanced ACh tone resulted in facilitation of whisker-evoked high-frequency oscillations with a concurrent decrease in low frequencies, which is consistent with previous reports after BF stimulation alone (Metherate et al., 1992), ACh modulation of sensory or motor responses, and during alertness or attention (Jones, 2004; Rodriguez et al., 2004; Fan et al., 2007; Goard and Dan, 2009; Pinto et al., 2013). The decrease of alpha activity may involve inhibition of SOM interneurons (Jensen and Mazaheri, 2010), as supported by their lack of c-Fos expression (our study) and selective hyperpolarization and reduced firing rate during active states such as whisking (Gentet et al., 2012; Lee et al., 2013).

\section{ACh as a requirement for optimal NVC responses to} whisker stimulation

The decreased whisker-evoked neuronal and CBF responses under chronic low ACh tone point to a role for ACh as an obligatory component of the evoked NVC responses to sensory stimulation. Previous studies on the loss of ACh input on cortical CBF are sparse and reported hypoperfusion after long-term ACh denervation (Waite et al., 1999). Our data further suggest that ACh denervation or loss of integrity of the ACh system, as seen in AD patients (Tong and Hamel, 1999; Mesulam, 2013) and AD mouse models (Aucoin et al., 2005), may contribute to the impaired sensory-evoked oscillations (Başar et al., 2016) and whiskerevoked CBF responses (Niwa et al., 2002; Nicolakakis et al., 


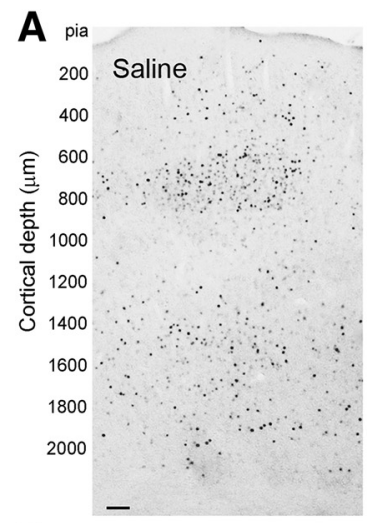

B

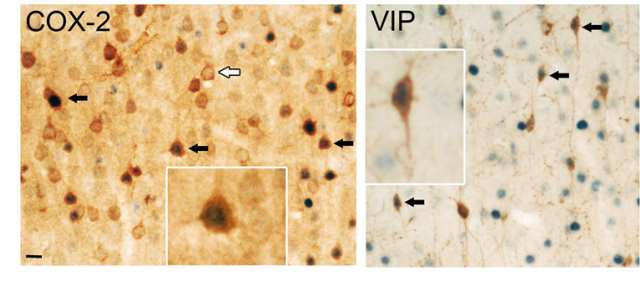

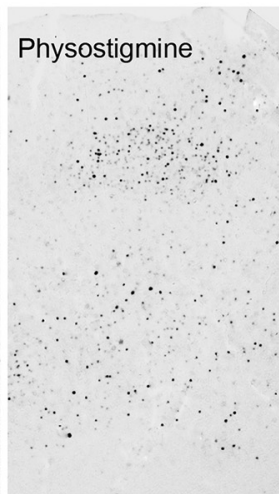
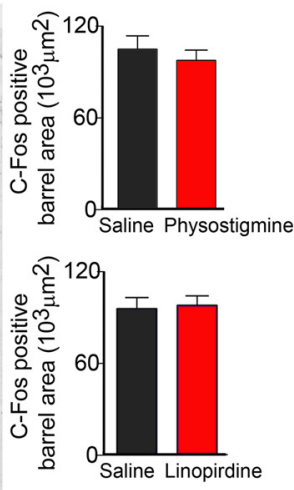
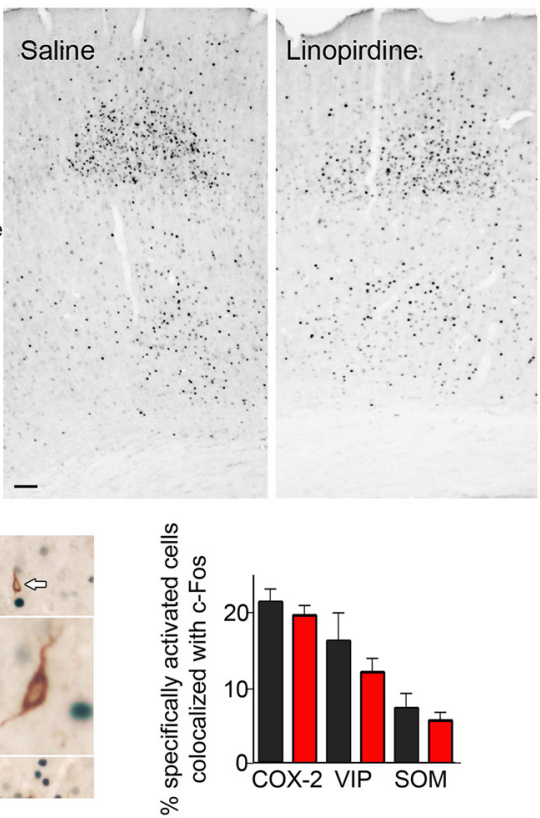

Figure 6. Size and extent of the activated (c-Fos) barrel cortex are not altered by enhanced ACh tone. The characteristic activation pattern (c-Fos-positive black nuclei) in layer IV of the contralateral barrel cortex after whisker stimulation was not altered by ACh enhancement $(\boldsymbol{A}$; linopirdine, $n=8$ or physostigmine, $n=8)$ compared with controls (saline, $n=9$ and 7 , respectively). Scale bar, $100 \mu \mathrm{m}$. Immunohistochemical identification of the activated neurons (C-Fos, blue nuclei) in the barrel cortex after whisker stimulation (B) revealed activation (black arrows) of COX-2 pyramidal cells and VIP interneurons compared with SOM interneurons, which were mainly unresponsive to the stimulus (white arrows point to nonactivated, $c$-Fos-negative cells). Scale bar, $5 \mu \mathrm{m}$. Quantitative analysis showed no change in the proportions of activated neurons after saline or linopirdine treatment (Student's $t$ test). Insets are higher magnification of double-labeled cells (COX-2 or VIP) or single-labeled SOM interneurons.

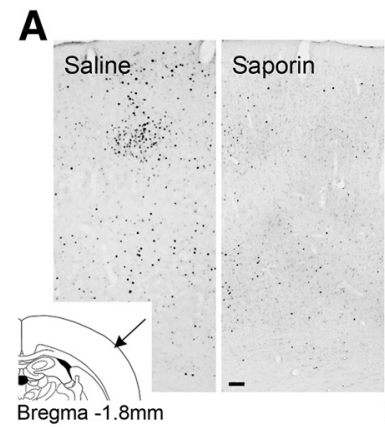

B

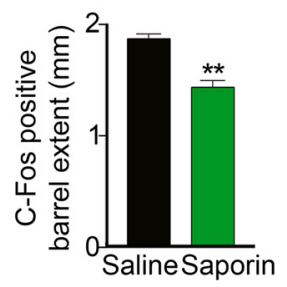

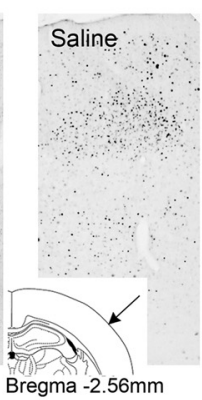
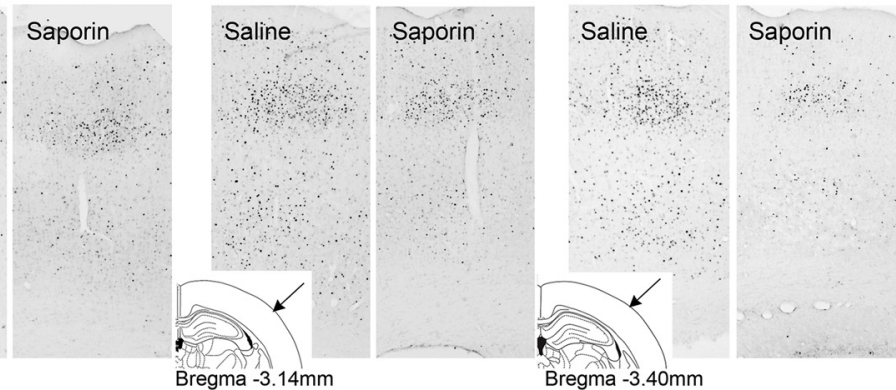

C

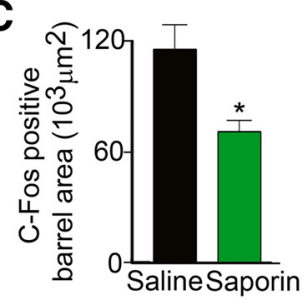

D

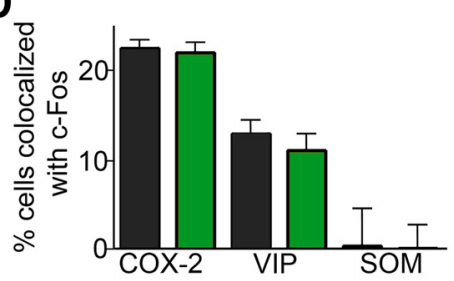

Figure 7. Decreased ACh tone reduces the size and extent of the activated ( $C$-Fos) barrel. Reduced cortical cholinergic innervation with saporin was associated with a significantly reduced whisker stimulation-induced c-Fos upregulation ( $\boldsymbol{A}$; black nuclei) in the contralateral barrel cortex compared with controls ( $n=4 / \mathrm{group})$ ). Scale bar, $100 \mu \mathrm{m}$. $\boldsymbol{B}, \boldsymbol{C}$, Cholinergic lesion decreased the rostrocaudal extent of the $c$-Fos-positive cells $(\boldsymbol{B})$ and the area they occupied in layer IV of the activated barrel $(\boldsymbol{C})$. In control rats, the barrel started, on average, at bregma level $-1.8 \mathrm{~mm}$, whereas in lesioned animals, it started at $\sim-2.2 \mathrm{~mm}$. In both conditions, the c-Fos barrel disappeared at approximately bregma $-3.7 \mathrm{~mm}$. D, Double immunohistochemistry of c-Fos and specific neuronal markers in the responsive barrel indicated that the typical pattern of activated COX-2 pyramidal cells and VIP interneurons, with virtually no SOM interneurons, was unaltered in ACh-depleted rats compared with controls ( ${ }^{*} p<0.05 ;{ }^{* *} p<0.01 ;{ }^{* * *} p<0.001$, Student's $t$ test).

2008). We found that chronic ACh depletion led to decreased power in most LFP frequency bands evoked by whisker stimulation with concurrent increases in theta band, which is similar to the distinctive shift of EEG toward slow oscillations after BF lesion or ACh antagonism (Buzsaki et al., 1988; Ebert and Kirch, 1998). Increases in low-frequency power were also observed after acute optogenetic inhibition of BF ACh neurons during spontaneous and running activity (Pinto et al., 2013). In addition, AD patients, whose extent of ACh denervation has been associated with increased theta and decreased gamma power (Moretti et al., 2008), display a similar pattern of decreased responses in beta and gamma frequency bands while performing a task (Kurimoto et 
Decreased ACh condition (Alzheimer's disease)

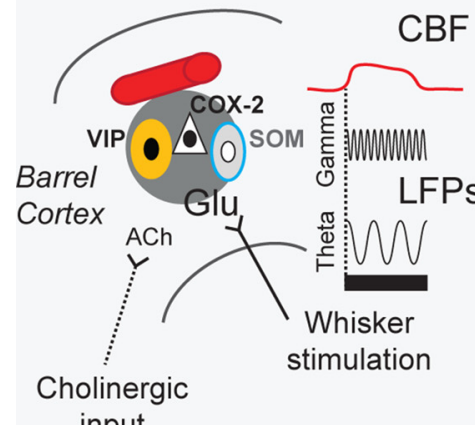

input

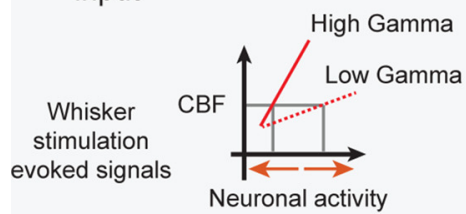

\section{Control condition}

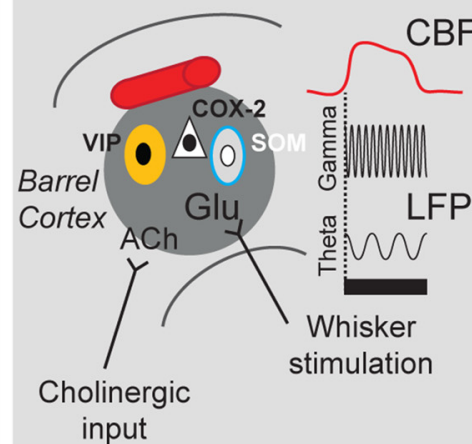

input

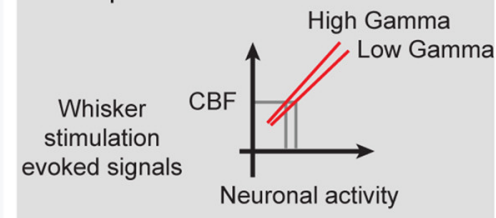

\section{Increased ACh condition} (alterness, attention)
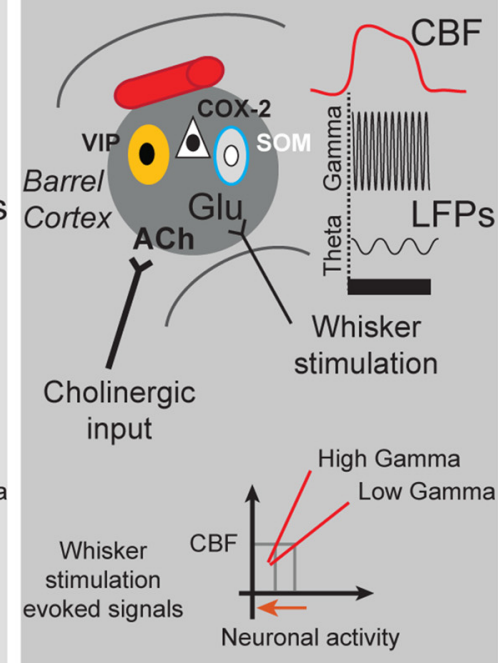

Figure 8. Summary of whisker-evoked CBF and neuronal responses as a function of ACh tone. In the responsive control barrel cortex (dark gray circle), VIP interneurons (yellow cells) and COX-2-expressing pyramidal cells (white triangle) are typically activated (black nucleus, c-Fos positive), (middle panel) by the glutamate released upon whisker stimulation (black bar), whereas SOM interneurons (gray cells) remain largely inhibited (white nucleus, c-Fos negative). In conditions of increased ACh tone (as seen during arousal and attention conditions, right panel), the cortical neuronal circuitry is identical, but the resulting (BF and high-frequency oscillations are potentiated. In contrast, decreased ACh neurotransmission (mimicking AD, left panel) contracted the activated barrel cortex and altered the evoked CBF and neuronal responses. These changes involved lower amplitude of gamma bands and higher amplitude of low-frequency theta band, which results in altered fidelity of the correlations between LFP frequency bands and hemodynamics. Specifically, different levels of neuronal activity (orange arrows, bottom of panels) are needed for an equivalent whisker-evoked CBF response depending on ACh tone.

al., 2012). Therefore, our findings infer a crucial role of ACh denervation in the EEG alterations seen in AD. Most importantly, alteration in ACh tone may underlie the deficits in visual, auditory, and olfactory event-related potentials reported in $\mathrm{AD}$ patients (Saito et al., 2001; Morgan and Murphy, 2002; Golob et al., 2009; Bender et al., 2014).

ACh tone is reflected in NVC responses to whisker responses Under control ACh tone, high-frequency LFP bands were more informative about evoked CBF than low-frequency LFP bands, in agreement with previous studies (Mukamel et al., 2005; Goense and Logothetis, 2008; Sumiyoshi et al., 2012) and with the known correlation of gamma oscillations with hemodynamic signals (Logothetis et al., 2001; Niessing et al., 2005; Shmuel and Leopold, 2008). Few studies investigated the impact of cortical desynchronization on evoked hemodynamics and electrophysiology (Niessing et al., 2005; Jones, 2008; Slack et al., 2016) and the mechanisms linking hemodynamic signals to specific neuronal events remain poorly understood. Here, we report alterations of NVC across ACh tones suggesting that sensory evoked-CBF does not merely reflect the sensory-evoked neuronal responses, but also its concurrent modulation by ACh. Our finding of steeper slopes of correlations between high-gamma oscillations and CBF was found recently in normal aging (Jessen et al., 2015), where progressive ACh denervation occurs (Tong and Hamel, 1999; Schliebs and Arendt, 2011). Furthermore, high-gamma oscillations are tightly correlated with spiking activity (Ray and Maunsell, 2011), which also correlates with CBF (Lima et al., 2014). These high-gamma/CBF correlations may involve distinct mechanisms with improved sensory network processing (Goard and Dan, 2009) in the enhanced ACh condition, whereas compensatory mechanisms may be involved under low ACh tone. These may include higher activity in the saporin-resistant BF GABAergic neurons that can also drive cortical gamma oscillations (Lin et al., 2006; Kim et al., 2015) or increased density of dendritic spines on cortical pyramidal cells (Works et al., 2004). However, such corrective mechanisms failed to drive a normal whisker-evoked CBF response.

\section{ACh alters the activity, but not the identity, of the network processing sensory information}

The neuronal networks anatomically identified by c-Fos upregulation in the somatosensory cortex after whisker and suprathreshold $\mathrm{BF}$ ACh neuron stimulation are very characteristic and highly discriminative, with respective predominant activation of VIP-containing (Lecrux et al., 2011) and SOM-containing (Kocharyan et al., 2008) GABA interneurons. These c-Fos patterns match very well with the cortical microcircuit identified through electrophysiology and optogenetic manipulations upon whisker stimulation (Gentet et al., 2012; Lee et al., 2013; Pi et al., 2013) and ACh activation (Chen et al., 2015). Interestingly, the identity of the cortical network processing sensory information under enhanced ACh was unchanged, suggesting that SOM cells were only weakly activated by our subthreshold ACh-promoting manipulations. It thus appears that ACh may play a key role in modulating the strength of inhibition through VIP interneurons in states of increased awareness, attention, or in the awake cortex (Haider et al., 2013), as supported by the increased visual responses in V1 after ACh-mediated activation of VIP neurons (Fu et al., 2014).

Under conditions of chronically reduced ACh input to the cortex, impaired NVC responses to whisker stimulation were associated with a constricted barrel area occupied by c-Fos-immunopositive cells. Such reduction most likely reflects impaired whisker-evoked neuronal activity rather than a decrease in the number of neurons within the barrel because cortical neurons are preserved in saporintreated rats (Rossner et al., 1995). Our anatomical findings agree with the reported diminished whisker-evoked firing across the barrel 
cortex (Herron and Schweitzer, 2000) and decreased mean response probability of layer II/III interneurons (Kerr et al., 2007) after ACh depletion. Because ACh may lower tonically the threshold of input required to promote action potential firing in neurons in the barrel, ACh depletion might hinder the firing of thalamocortical recipient neurons in response to whisker stimulation. This could explain the narrowing of the activated barrel and impaired NVC response compared with control and enhanced ACh tone.

\section{Study limitations and future perspectives}

The present investigation used various pharmacological manipulations and electrical stimulations of the $\mathrm{BF}$ to increase cholinergic tone, together with different stimulation paradigms for whisker stimulation depending on the specific experiments. Although these yielded consistent findings, optogenetically driven activation or inhibition of ACh-releasing neurons (Witten et al., 2011) and targeting of ACh receptors either broadly (Wess et al., 2007; Zhang et al., 2016) or in specific cell types (Jeon et al., 2010) would be required to extend upon the current findings. In addition, whether the reported effects would be maintained under a range of stimulation durations or different anesthetic regimens and how the changes in cortical hemodynamic responses are altered spatially remain challenging questions to be addressed in order to fully decipher the modulatory role of ACh on sensoryevoked NVC responses.

\section{Conclusions}

Our findings unveil an essential role for ACh in enabling optimal activity within the neuronal network transducing sensoryevoked neural activity in vascular signals. Our data indicate that ACh levels alter the fidelity of evoked CBF in assessing underlying neuronal activity. Therefore, altered ACh tone, as found in neurodegenerative diseases and across brain states such as attention and arousal, should be taken into account when relying on NVC to estimate brain activity.

\section{References}

Aucoin JS, Jiang P, Aznavour N, Tong XK, Buttini M, Descarries L, Hamel E (2005) Selective cholinergic denervation, independent from oxidative stress, in a mouse model of Alzheimer's disease. Neuroscience 132:73-86. CrossRef Medline

Başar E, Emek-Savaş DD, Güntekin B, Yener GG (2016) Delay of cognitive gamma responses in Alzheimer's disease. Neuroimage Clin 11:106-115. CrossRef Medline

Bender S, Bluschke A, Dippel G, Rupp A, Weisbrod M, Thomas C (2014) Auditory post-processing in a passive listening task is deficient in Alzheimer's disease. Clin Neurophysiol 125:53-62. CrossRef Medline

Bhat RV, Turner SL, Marks MJ, Collins AC (1990) Selective changes in sensitivity to cholinergic agonists and receptor changes elicited by continuous physostigmine infusion. J Pharmacol Exp Ther 255:187-196. Medline

Buzsaki G, Bickford RG, Ponomareff G, Thal LJ, Mandel R, Gage FH (1988) Nucleus basalis and thalamic control of neocortical activity in the freely moving rat. J Neurosci 8:4007-4026. Medline

Cape EG, Manns ID, Alonso A, Beaudet A, Jones BE (2000) Neurotensininduced bursting of cholinergic basal forebrain neurons promotes gamma and theta cortical activity together with waking and paradoxical sleep. J Neurosci 20:8452-8461. Medline

Chaudhury D, Escanilla O, Linster C (2009) Bulbar acetylcholine enhances neural and perceptual odor discrimination. J Neurosci 29:52-60. CrossRef Medline

Chen G, Yan J (2007) Cholinergic modulation incorporated with a tone presentation induces frequency-specific threshold decreases in the auditory cortex of the mouse. Eur J Neurosci 25:1793-1803. CrossRef Medline

Chen N, Sugihara H, Sur M (2015) An acetylcholine-activated microcircuit drives temporal dynamics of cortical activity. Nat Neurosci 18:892-902. CrossRef Medline

Ebert U, Kirch W (1998) Scopolamine model of dementia: electroencepha- logram findings and cognitive performance. Eur J Clin Invest 28:944949. CrossRef Medline

Elhusseiny A, Hamel E (2000) Muscarinic-but not nicotinic-acetylcholine receptors mediate a nitric oxide-dependent dilation in brain cortical arterioles: a possible role for the M5 receptor subtype. J Cereb Blood Flow Metab 20:298-305. Medline

Fan J, Byrne J, Worden MS, Guise KG, McCandliss BD, Fossella J, Posner MI (2007) The relation of brain oscillations to attentional networks. J Neurosci 27:6197-6206. CrossRef Medline

Fazlali Z, Ranjbar-Slamloo Y, Adibi M, Arabzadeh E (2016) Correlation between cortical state and locus coeruleus activity: implications for sensory coding in rat barrel cortex. Front Neural Circuits 10:14. CrossRef Medline

Fredriksson I, Larsson M, Strömberg T (2009) Measurement depth and volume in laser Doppler flowmetry. Microvasc Res 78:4-13. CrossRef Medline

Freeman JA, Nicholson C (1975) Experimental optimization of current source-density technique for anuran cerebellum. J Neurophysiol 38:369 382. Medline

Fu Y, Tucciarone JM, Espinosa JS, Sheng N, Darcy DP, Nicoll RA, Huang ZJ, Stryker MP (2014) A cortical circuit for gain control by behavioral state. Cell 156:1139-1152. CrossRef Medline

Gentet LJ, Kremer Y, Taniguchi H, Huang ZJ, Staiger JF, Petersen CC (2012) Unique functional properties of somatostatin-expressing GABAergic neurons in mouse barrel cortex. Nat Neurosci 15:607-612. CrossRef Medline

Goard M, Dan Y (2009) Basal forebrain activation enhances cortical coding of natural scenes. Nat Neurosci 12:1444-1449. CrossRef Medline

Goense JB, Logothetis NK (2008) Neurophysiology of the BOLD fMRI signal in awake monkeys. Curr Biol 18:631-640. CrossRef Medline

Golob EJ, Ringman JM, Irimajiri R, Bright S, Schaffer B, Medina LD, Starr A (2009) Cortical event-related potentials in preclinical familial Alzheimer disease. Neurology 73:1649-1655. CrossRef Medline

Groleau M, Nguyen HN, Vanni MP, Huppé-Gourgues F, Casanova C, Vaucher E (2014) Impaired functional organization in the visual cortex of muscarinic receptor knock-out mice. Neuroimage 98:233-242. CrossRef Medline

Gulledge AT, Bucci DJ, Zhang SS, Matsui M, Yeh HH (2009) M1 receptors mediate cholinergic modulation of excitability in neocortical pyramidal neurons. J Neurosci 29:9888-9902. CrossRef Medline

Haider B, Häusser M, Carandini M (2013) Inhibition dominates sensory responses in the awake cortex. Nature 493:97-100. CrossRef Medline

Harris KD, Thiele A (2011) Cortical state and attention. Nat Rev Neurosci 12:509-523. CrossRef Medline

Harris S, Ma H, Zhao M, Boorman L, Zheng Y, Kennerley A, Bruyns-Haylett M, Overton PG, Berwick J, Schwartz TH (2014) Coupling between gamma-band power and cerebral blood volume during recurrent acute neocortical seizures. Neuroimage 97:62-70. CrossRef Medline

Hasselmo ME, Sarter M (2011) Modes and models of forebrain cholinergic neuromodulation of cognition. Neuropsychopharmacology 36:52-73. CrossRef Medline

Herrero JL, Roberts MJ, Delicato LS, Gieselmann MA, Dayan P, Thiele A (2008) Acetylcholine contributes through muscarinic receptors to attentional modulation in V1. Nature 454:1110-1114. CrossRef Medline

Herron P, Schweitzer JB (2000) Effects of cholinergic depletion on neural activity in different laminae of the rat barrel cortex. Brain Res 872:71-76. CrossRef Medline

Hillman EM (2014) Coupling mechanism and significance of the BOLD signal: a status report. Annu Rev Neurosci 37:161-181. CrossRef Medline

Jensen O, Mazaheri A (2010) Shaping functional architecture by oscillatory alpha activity: gating by inhibition. Front Hum Neurosci 4:186. CrossRef Medline

Jeon J, Dencker D, Wörtwein G, Woldbye DP, Cui Y, Davis AA, Levey AI, Schütz G, Sager TN, Mørk A, Li C, Deng CX, Fink-Jensen A, Wess J (2010) A subpopulation of neuronal M4 muscarinic acetylcholine receptors plays a critical role in modulating dopamine-dependent behaviors. J Neurosci 30:2396-2405. CrossRef Medline

Jessen SB, Mathiesen C, Lind BL, Lauritzen M (2015) Interneuron deficit associates attenuated network synchronization to mismatch of energy supply and demand in aging mouse brains. Cereb Cortex. Advance online publication. Retrieved October 29, 2015. doi:10.1093/cercor/bhv261.

Jones BE (2004) Activity, modulation and role of basal forebrain cholinergic neurons innervating the cerebral cortex. Prog Brain Res 145:157-169. CrossRef Medline 
Jones BE (2008) Modulation of cortical activation and behavioral arousal by cholinergic and orexinergic systems. Ann N Y Acad Sci 1129:26-34. CrossRef Medline

Jones M, Hewson-Stoate N, Martindale J, Redgrave P, Mayhew J (2004) Nonlinear coupling of neural activity and CBF in rodent barrel cortex. Neuroimage 22:956-965. CrossRef Medline

Kalmbach A, Waters J (2014) Modulation of high- and low-frequency components of the cortical local field potential via nicotinic and muscarinic acetylcholine receptors in anesthetized mice. J Neurophysiol 111:258272. CrossRef Medline

Kerr JN, de Kock CP, Greenberg DS, Bruno RM, Sakmann B, Helmchen F (2007) Spatial organization of neuronal population responses in layer 2/3 of rat barrel cortex. J Neurosci 27:13316-13328. CrossRef Medline

Kilgard MP, Merzenich MM (1998) Cortical map reorganization enabled by nucleus basalis activity. Science 279:1714-1718. CrossRef Medline

Kim T, Thankachan S, McKenna JT, McNally JM, Yang C, Choi JH, Chen L, Kocsis B, Deisseroth K, Strecker RE, Basheer R, Brown RE, McCarley RW (2015) Cortically projecting basal forebrain parvalbumin neurons regulate cortical gamma band oscillations. Proc Natl Acad Sci U S A 112:35353540. CrossRef Medline

Kocharyan A, Fernandes P, Tong XK, Vaucher E, Hamel E (2008) Specific subtypes of cortical GABA interneurons contribute to the neurovascular coupling response to basal forebrain stimulation. J Cereb Blood Flow Metab 28:221-231. CrossRef Medline

Kurimoto R, Ishii R, Canuet L, Ikezawa K, Iwase M, Azechi M, Aoki Y, Ikeda S, Yoshida T, Takahashi H, Nakahachi T, Kazui H, Takeda M (2012) Induced oscillatory responses during the Sternberg's visual memory task in patients with Alzheimer's disease and mild cognitive impairment. Neuroimage 59:4132-4140. CrossRef Medline

Lacroix A, Toussay X, Anenberg E, Lecrux C, Ferreirós N, Karagiannis A, Plaisier F, Chausson P, Jarlier F, Burgess SA, Hillman EM, Tegeder I, Murphy TH, Hamel E, Cauli B (2015) COX-2-derived prostaglandin E2 produced by pyramidal neurons contributes to neurovascular coupling in the rodent cerebral cortex. J Neurosci 35:11791-11810. CrossRef Medline

Lauritzen M, Gold L (2003) Brain function and neurophysiological correlates of signals used in functional neuroimaging. J Neurosci 23:39723980. Medline

Lecrux C, Hamel E (2016) Neuronal networks and mediators of cortical neurovascular coupling responses in normal and altered brain states. Philos Trans R Soc Lond B Biol Sci 371(1705):pii:20150350. Medline

Lecrux C, Toussay X, Kocharyan A, Fernandes P, Neupane S, Lévesque M, Plaisier F, Shmuel A, Cauli B, Hamel E (2011) Pyramidal neurons are "neurogenic hubs" in the neurovascular coupling response to whisker stimulation. J Neurosci 31:9836-9847. CrossRef Medline

Lecrux C, Kocharyan A, Sandoe CH, Tong XK, Hamel E (2012) Pyramidal cells and cytochrome P450 epoxygenase products in the neurovascular coupling response to basal forebrain cholinergic input. J Cereb Blood Flow Metab 32:896-906. CrossRef Medline

Lee S, Kruglikov I, Huang ZJ, Fishell G, Rudy B (2013) A disinhibitory circuit mediates motor integration in the somatosensory cortex. Nat Neurosci 16:1662-1670. CrossRef Medline

Li CY, Poo MM, Dan Y (2009) Burst spiking of a single cortical neuron modifies global brain state. Science 324:643-646. CrossRef Medline

Lima B, Cardoso MM, Sirotin YB, Das A (2014) Stimulus-related neuroimaging in task-engaged subjects is best predicted by concurrent spiking. J Neurosci 34:13878-13891. CrossRef Medline

Lin SC, Gervasoni D, Nicolelis MA (2006) Fast modulation of prefrontal cortex activity by basal forebrain noncholinergic neuronal ensembles. J Neurophysiol 96:3209-3219. CrossRef Medline

Liu JV, Hirano Y, Nascimento GC, Stefanovic B, Leopold DA, Silva AC (2013) fMRI in the awake marmoset: somatosensory-evoked responses, functional connectivity, and comparison with propofol anesthesia. Neuroimage 78:186-195. CrossRef Medline

Logothetis NK, Pauls J, Augath M, Trinath T, Oeltermann A (2001) Neurophysiological investigation of the basis of the fMRI signal. Nature 412: 150-157. CrossRef Medline

Lübke J, Feldmeyer D (2007) Excitatory signal flow and connectivity in a cortical column: focus on barrel cortex. Brain Struct Funct 212:3-17. CrossRef Medline

Magri C, Schridde U, Murayama Y, Panzeri S, Logothetis NK (2012) The amplitude and timing of the BOLD signal reflects the relationship be- tween local field potential power at different frequencies. J Neurosci 32: 1395-1407. CrossRef Medline

Marenco T, Bernstein S, Cumming P, Clarke PB (2000) Effects of nicotine and chlorisondamine on cerebral glucose utilization in immobilized and freely-moving rats. Br J Pharmacol 129:147-155. CrossRef Medline

Martindale J, Mayhew J, Berwick J, Jones M, Martin C, Johnston D, Redgrave P, Zheng Y (2003) The hemodynamic impulse response to a single neural event. J Cereb Blood Flow Metab 23:546-555. Medline

Masamoto K, Kanno I (2012) Anesthesia and the quantitative evaluation of neurovascular coupling. J Cereb Blood Flow Metab 32:1233-1247. CrossRef Medline

Mesik L, Ma WP, Li LY, Ibrahim LA, Huang ZJ, Zhang LI, Tao HW (2015) Functional response properties of VIP-expressing inhibitory neurons in mouse visual and auditory cortex. Front Neural Circuits 9:22. CrossRef Medline

Mesulam MM (2013) Cholinergic circuitry of the human nucleus basalis and its fate in Alzheimer's disease. J Comp Neurol 521:4124-4144. CrossRef Medline

Metherate R, Tremblay N, Dykes RW (1988) The effects of acetylcholine on response properties of cat somatosensory cortical neurons. J Neurophysiol 59:1231-1252. Medline

Metherate R, Cox CL, Ashe JH (1992) Cellular bases of neocortical activation: modulation of neural oscillations by the nucleus basalis and endogenous acetylcholine. J Neurosci 12:4701-4711. Medline

Meyer E, Ferguson SS, Zatorre RJ, Alivisatos B, Marrett S, Evans AC, Hakim AM (1991) Attention modulates somatosensory cerebral blood flow response to vibrotactile stimulation as measured by positron emission tomography. Ann Neurol 29:440-443. CrossRef Medline

Montez T, Poil SS, Jones BF, Manshanden I, Verbunt JP, van Dijk BW, Brussaard AB, van Ooyen A, Stam CJ, Scheltens P, Linkenkaer-Hansen K (2009) Altered temporal correlations in parietal alpha and prefrontal theta oscillations in early-stage Alzheimer disease. Proc Natl Acad Sci U S A 106:1614-1619. CrossRef Medline

Moretti DV, Pievani M, Fracassi C, Geroldi C, Calabria M, De Carli CS, Rossini PM, Frisoni GB (2008) Brain vascular damage of cholinergic pathways and EEG markers in mild cognitive impairment. J Alzheimers Dis 15:357-372. Medline

Morgan CD, Murphy C (2002) Olfactory event-related potentials in Alzheimer's disease. J Int Neuropsychol Soc 8:753-763. CrossRef Medline

Mukamel R, Gelbard H, Arieli A, Hasson U, Fried I, Malach R (2005) Coupling between neuronal firing, field potentials, and FMRI in human auditory cortex. Science 309:951-954. CrossRef Medline

Nakao Y, Gotoh J, Kuang TY, Cohen DM, Pettigrew KD, Sokoloff L (1999) Cerebral blood flow responses to somatosensory stimulation are unaffected by scopolamine in unanesthetized rat. J Pharmacol Exp Ther 290: 929-934. Medline

Nasrallah FA, Lew SK, Low AS, Chuang KH (2014) Neural correlate of resting-state functional connectivity under alpha2 adrenergic receptor agonist, medetomidine. Neuroimage 84:27-34. CrossRef Medline

Nicolakakis N, Aboulkassim T, Ongali B, Lecrux C, Fernandes P, Rosa-Neto P, Tong XK, Hamel E (2008) Complete rescue of cerebrovascular function in aged Alzheimer's disease transgenic mice by antioxidants and pioglitazone, a peroxisome proliferator-activated receptor gamma agonist. J Neurosci 28:9287-9296. CrossRef Medline

Niessing J, Ebisch B, Schmidt KE, Niessing M, Singer W, Galuske RA (2005) Hemodynamic signals correlate tightly with synchronized gamma oscillations. Science 309:948-951. CrossRef Medline

Niwa K, Kazama K, Younkin L, Younkin SG, Carlson GA, Iadecola C (2002) Cerebrovascular autoregulation is profoundly impaired in mice overexpressing amyloid precursor protein. Am J Physiol Heart Circ Physiol 283:H315-323. CrossRef Medline

Nuñez A, Domínguez S, Buño W, Fernández de Sevilla D (2012) Cholinergic-mediated response enhancement in barrel cortex layer V pyramidal neurons. J Neurophysiol 108:1656-1668. CrossRef Medline

Oldford E, Castro-Alamancos MA (2003) Input-specific effects of acetylcholine on sensory and intracortical evoked responses in the "barrel cortex" in vivo. Neuroscience 117:769-778. CrossRef Medline

Pawela CP, Biswal BB, Hudetz AG, Schulte ML, Li R, Jones SR, Cho YR, Matloub HS, Hyde JS (2009) A protocol for use of medetomidine anesthesia in rats for extended studies using task-induced BOLD contrast and resting-state functional connectivity. Neuroimage 46:1137-1147. CrossRef Medline 
Paxinos G, Watson C (1998) The rat brain in stereotaxic coordinates. San Diego: Academic.

Peeters RR, Tindemans I, De Schutter E, Van der Linden A (2001) Comparing BOLD fMRI signal changes in the awake and anesthetized rat during electrical forepaw stimulation. Magn Reson Imaging 19:821-826. CrossRef Medline

Penschuck S, Chen-Bee CH, Prakash N, Frostig RD (2002) In vivo modulation of a cortical functional sensory representation shortly after topical cholinergic agent application. J Comp Neurol 452:38-50. CrossRef Medline

Pi HJ, Hangya B, Kvitsiani D, Sanders JI, Huang ZJ, Kepecs A (2013) Cortical interneurons that specialize in disinhibitory control. Nature 503: 521-524. CrossRef Medline

Pinto L, Goard MJ, Estandian D, Xu M, Kwan AC, Lee SH, Harrison TC, Feng G, Dan Y (2013) Fast modulation of visual perception by basal forebrain cholinergic neurons. Nat Neurosci 16:1857-1863. CrossRef Medline

Ray S, Maunsell JH (2011) Different origins of gamma rhythm and highgamma activity in macaque visual cortex. PLoS Biol 9:e1000610. CrossRef Medline

Ren JQ, Aika Y, Heizmann CW, Kosaka T (1992) Quantitative analysis of neurons and glial cells in the rat somatosensory cortex, with special reference to GABAergic neurons and parvalbumin-containing neurons. Exp Brain Res 92:1-14. CrossRef Medline

Rodriguez R, Kallenbach U, Singer W, Munk MH (2004) Short- and longterm effects of cholinergic modulation on gamma oscillations and response synchronization in the visual cortex. J Neurosci 24:10369-10378. CrossRef Medline

Rossner S, Schliebs R, Härtig W, Bigl V (1995) 192IGG-saporin-induced selective lesion of cholinergic basal forebrain system: neurochemical effects on cholinergic neurotransmission in rat cerebral cortex and hippocampus. Brain Res Bull 38:371-381. CrossRef Medline

Saito H, Yamazaki H, Matsuoka H, Matsumoto K, Numachi Y, Yoshida S, Ueno T, Sato M (2001) Visual event-related potential in mild dementia of the Alzheimer's type. Psychiatry Clin Neurosci 55:365-371. CrossRef Medline

Sanganahalli BG, Herman P, Hyder F (2008) Frequency-dependent tactile responses in rat brain measured by functional MRI. NMR Biomed 21: 410-416. CrossRef Medline

Schliebs R, Arendt T (2011) The cholinergic system in aging and neuronal degeneration. Behav Brain Res 221:555-563. CrossRef Medline

Shmuel A, Leopold DA (2008) Neuronal correlates of spontaneous fluctuations in fMRI signals in monkey visual cortex: Implications for functional connectivity at rest. Hum Brain Mapp 29:751-761. CrossRef Medline

Shmuel A, Augath M, Oeltermann A, Logothetis NK (2006) Negative functional MRI response correlates with decreases in neuronal activity in monkey visual area V1. Nat Neurosci 9:569-577. CrossRef Medline

Slack R, Boorman L, Patel P, Harris S, Bruyns-Haylett M, Kennerley A, Jones M, Berwick J (2016) A novel method for classifying cortical state to identify the accompanying changes in cerebral hemodynamics. J Neurosci Methods 267:21-34. CrossRef Medline

Sotero RC, Bortel A, Naaman S, Mocanu VM, Kropf P, Villeneuve MY, Shmuel A (2015) Laminar distribution of phase-amplitude coupling of spontaneous current sources and sinks. Front Neurosci 9:454. CrossRef Medline

Staiger JF (2006) Immediate-early gene expression in the barrel cortex. Somatosens Mot Res 23:135-146. CrossRef Medline

Staiger JF, Bisler S, Schleicher A, Gass P, Stehle JH, Zilles K (2000) Exploration of a novel environment leads to the expression of inducible transcription factors in barrel-related columns. Neuroscience 99:7-16. CrossRef Medline

Sumiyoshi A, Suzuki H, Ogawa T, Riera JJ, Shimokawa H, Kawashima R (2012) Coupling between gamma oscillation and fMRI signal in the rat somatosensory cortex: its dependence on systemic physiological parameters. Neuroimage 60:738-746. CrossRef Medline

Thiele A (2013) Muscarinic signaling in the brain. Annu Rev Neurosci 36: 271-294. CrossRef Medline

Tong XK, Hamel E (1999) Regional cholinergic denervation of cortical microvessels and nitric oxide synthase-containing neurons in Alzheimer's disease. Neuroscience 92:163-175. CrossRef Medline

Tremblay N, Warren RA, Dykes RW (1990) Electrophysiological studies of acetylcholine and the role of the basal forebrain in the somatosensory cortex of the cat. I. Cortical neurons excited by glutamate. J Neurophysiol 64:1199-1211. Medline

Vaknin G, DiScenna PG, Teyler TJ (1988) A method for calculating current source density (CSD) analysis without resorting to recording sites outside the sampling volume. J Neurosci Methods 24:131-135. CrossRef Medline

Waite JJ, Holschneider DP, Scremin OU (1999) Selective immunotoxininduced cholinergic deafferentation alters blood flow distribution in the cerebral cortex. Brain Res 818:1-11. CrossRef Medline

Wess J, Eglen RM, Gautam D (2007) Muscarinic acetylcholine receptors: mutant mice provide new insights for drug development. Nat Rev Drug Discov 6:721-733. CrossRef Medline

Williams KA, Magnuson M, Majeed W, LaConte SM, Peltier SJ, Hu X, Keilholz SD (2010) Comparison of alpha-chloralose, medetomidine and isoflurane anesthesia for functional connectivity mapping in the rat. Magn Reson Imaging 28:995-1003. CrossRef Medline

Witten IB, Steinberg EE, Lee SY, Davidson TJ, Zalocusky KA, Brodsky M, Yizhar O, Cho SL, Gong S, Ramakrishnan C, Stuber GD, Tye KM, Janak PH, Deisseroth K (2011) Recombinase-driver rat lines: tools, techniques, and optogenetic application to dopamine-mediated reinforcement. Neuron 72:721-733. CrossRef Medline

Works SJ, Wilson RE, Wellman CL (2004) Age-dependent effect of cholinergic lesion on dendritic morphology in rat frontal cortex. Neurobiol Aging 25:963-974. CrossRef Medline

Yamada M, Lamping KG, Duttaroy A, Zhang W, Cui Y, Bymaster FP, McKinzie DL, Felder CC, Deng CX, Faraci FM, Wess J (2001) Cholinergic dilation of cerebral blood vessels is abolished in M(5) muscarinic acetylcholine receptor knockout mice. Proc Natl Acad Sci U S A 98:1409614101. CrossRef Medline

Zaczek R, Chorvat RJ, Brown BS (1997) Linopirdine: pharmacology of a neurotransmitter release enhancer. CNS Drug Rev 3:16.

Zhang JC, Yao W, Ren Q, Yang C, Dong C, Ma M, Wu J, Hashimoto K (2016) Depression-like phenotype by deletion of alpha7 nicotinic acetylcholine receptor: Role of BDNF-TrkB in nucleus accumbens. Sci Rep 6:36705. CrossRef Medline 